\title{
علاقة كل من التفكير الإبتكارى ومفهوم الذات بالبيئة المدرسية لاى تلاميذ المرحلة المتوسطة بالكويت
}

\author{
إعــداد \\ د. سميرة على حسن المذكوري \\ أستاذ مساعد- كلية التربية الأساسية السنية \\ الهيئة العامة للتعليم التطبيقي والتدريب
}

مجلة الدراسات التربوية والانسانية ـ كلية التربية ـ جامعة دمنهور

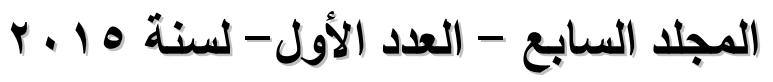


مجلة الدراسات التريوية والانسانية ـ كلية التربية ـ جامعة دمنهور. المجلد السابع- العدد( ()- لسنة ه 1 . ب 
علاقة كل من التفكير الإبتكارى ومفهوم الذات

\section{بالبيئة المدرسية لدى تلاميذ المرحلة المتوسطة بالكويت}

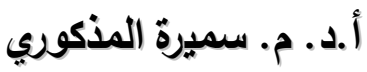

\section{مقدمه}

تعتبر الثروة البشرية أغلى ما يمكن أن تملكه المجتمعات من الثروات، وقد

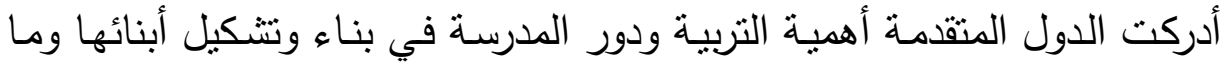

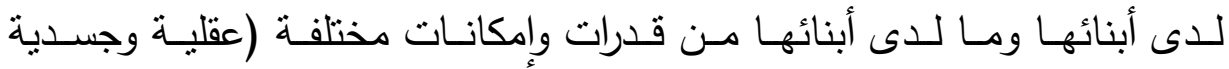

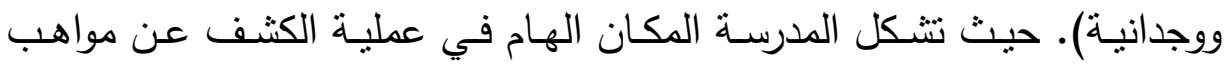
الطفل، وصقل قدراته الابتكارية، وفي هذه المؤسسات تتوافر الفرص التي يمكن

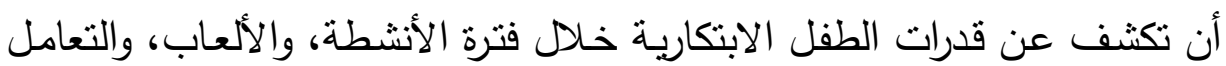
مع الرسائل التعليمية المختلفة المنوافرة، بالإضـافة إلى فرص تفاعل الأطفال مـع نفسهم وأقرناهم.

فالطفل الذي ينشأن على تلقي الأوامر والنواهي والإذعان لتوجيهات الكبار، لهار وتلقي المعرفة عن طريق التلقين والنسـخ وحشو العقل دون مشـاركة في كسب

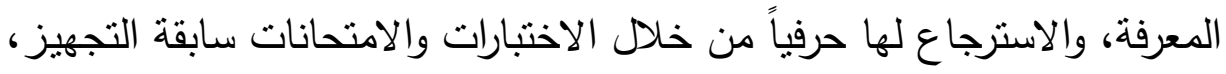
تتربى نفسيته وذهنه على موقف سلبي من نفسه ومن غيره، ومن الحياة والكون، ويكون دائماً في وضعية إذعان، بحيث يلوذ بالموروث ينشد فيه حل المشكلات،

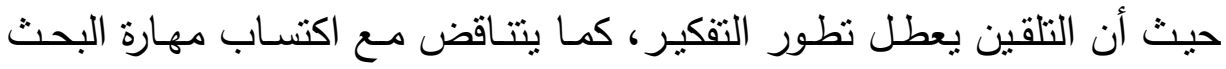
والتقصي في الواقع وتدريب مهارة الابتكار ، فالتلقين بعطل قدرة التقكير النقدي

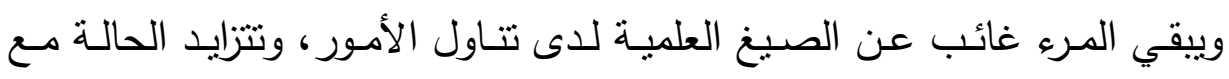
(http://www.diwanalarab.com) اعتماد التخويف والترويع كأداة تربية وتهذيب للنشه والابتكـار ظـاهرة إنسـانية معقدة ومتعـددة الجوانـب تقدرها كـل الجماعـات والثقافات المختلفة، فتقدم أي مجتمع أو تطوره يكمن في التعرف على ما لديه من قدرات ابتكارية كامنة وتوفير المناسب لهم، ورعايتهم والحفاظ عليهم عند تتاول Doi: 10.12816/0034808 
أي ظاهرة نفسية، ولا يمكن إغفال أثر البيئة الخارجية على هذه الظاهرة، فمفوم

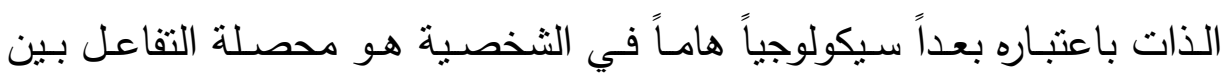

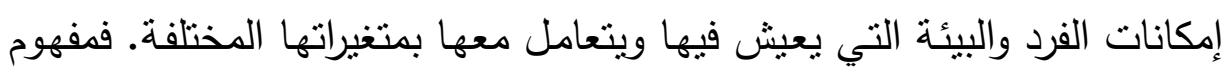

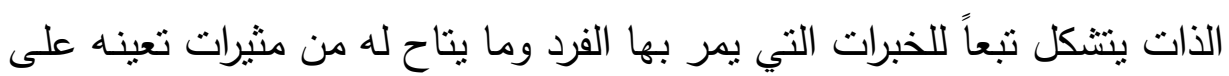

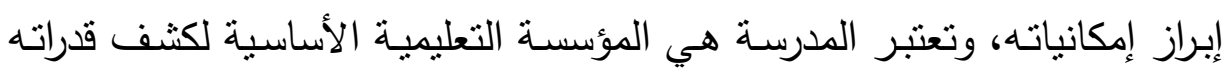

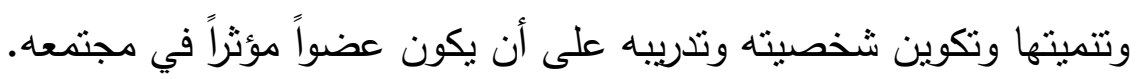
مشكلة الدراسة ونئة ونكوين

الاهتمـام بـالتعليم يعتبر ظـاهرة عامـة في الدول العربيـة وفي مصـر -بصفة

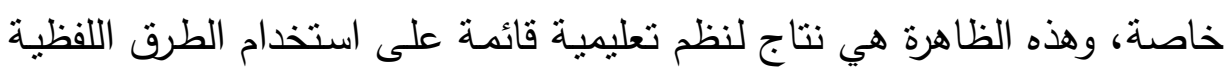

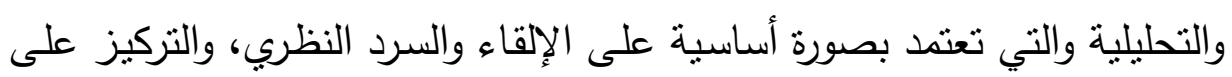

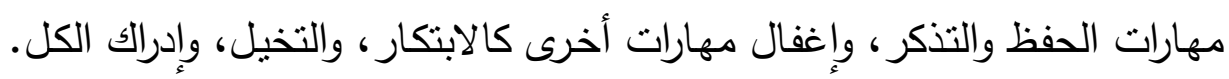
بسبب التوجـه بالكامل نحو التحصيل الدراسي بهدف النجاح واجتياز الامتحسان

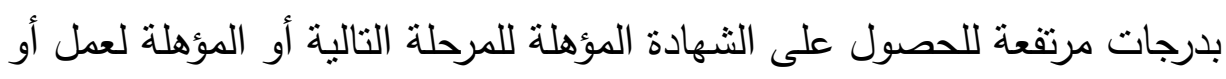

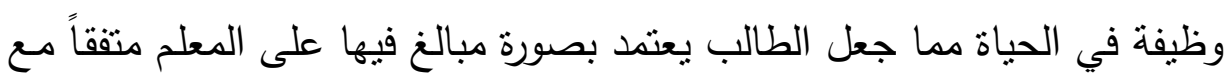
طريقة تدريسه ومسايراً للكتب في محتواه في عملية تعلمهاه، والعمل على تعزيز

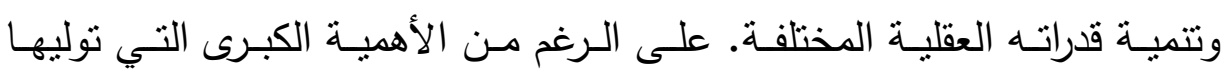
الأبحاث والدراسات الأجنبية للبيئة الابتكارية، والعوامل الميسرة للتقكير الابتكاري. لألهيه فلا يمكن إغفال دور البيئة الددرسية بصفة عامـة في ظل أساليب التعلم الحديثة - بصفة خاصة - في تأثثرها على تكوين شخصية الفرد واكتشاف قدراته ومواهبه وتتميتها من خـلال تشـيع الابتكار وإطلاق طاقة المتعلم الإبداعيـة من خـلال الاطلاع على التراث السيكولوجي والأطر النظرية، والدراسات البحثية التي اهتمت الإني

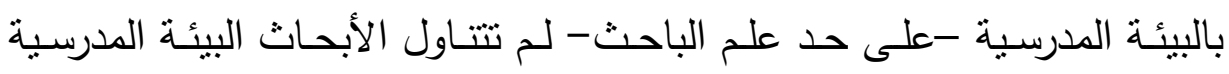

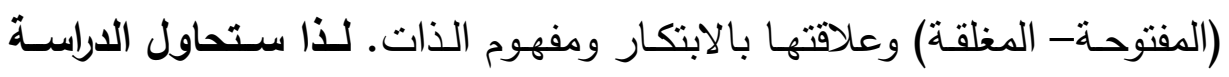
تناول هذا الموضوع من خلال الإجابة على التساؤلات الآتية: 
1-ما الفروق بين البيئات المدرسية المختلفة (الحكومية- اللغات (التجريبية) -

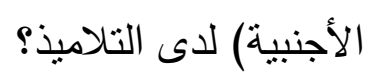

r-ما الفروق بين البيئات المدرسية المختلفة (الحكومية- اللغات (التجريبية) الأجنبية) ومفهوم الذات لاى التلاميذ؟ لاتبن

r-هل يختلف مفهوم الذات والابتكار لدى الجنسين باختلاف البيئات المدرسية

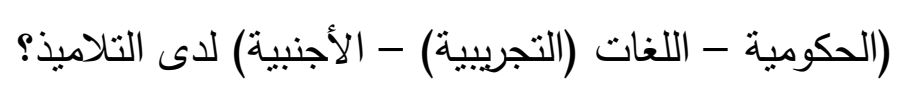

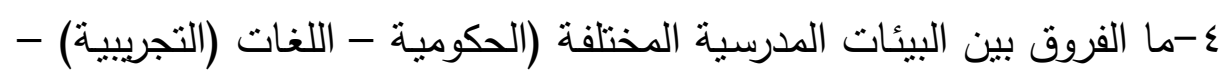

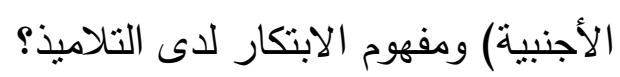

ه-هل يختلف مفهوم الذات لاى الجنسين باختلاف البيئات المدرسية (الحكومية

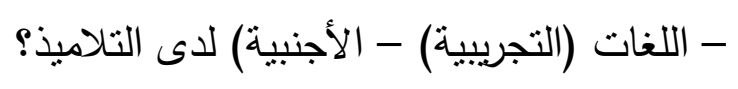

צ-هل يختلف الابتكار لدى الجنسين باختلاف البيئات المدرسية (الحكومية -

$$
\text { اللغات (التجربيية) - الأجنبية)؟ }
$$

\section{أهمية الاراسة}

تكمن أهمية هذه الدراسة في أن النظام التعليمي في الكثير من الدول العربية

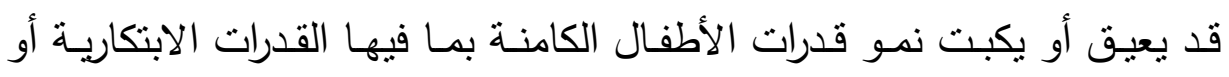

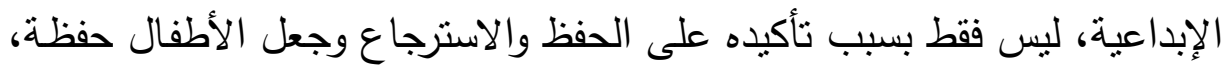

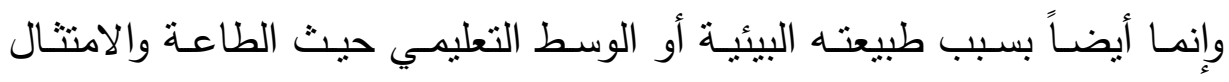
والسلبية في معاملة التلميذ. لذا يحتاج الأطفال في المراحل التعليمية إلى تدريبات موجهة لاستتارة الجوانب المختلفة الخاصة بالخيال، ولن يكون ذلك ممكناً إلا من خلال إيجاد بيئة منزلية

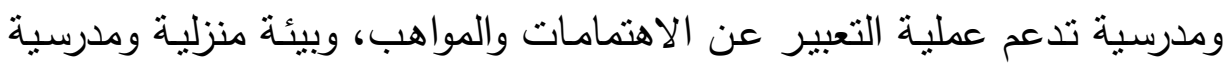

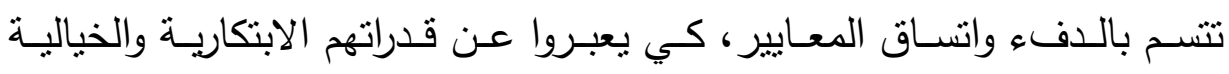

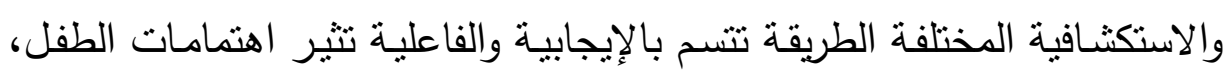

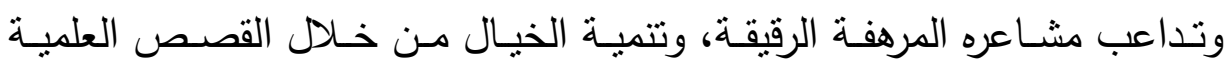


الخياليـة للاختراعـات والمسـتقبل، فهي تعـد بـذلك لجهيز عقل الطفل وذكائهـ للاختراع والابتكار. (http://www.Khayma .com)

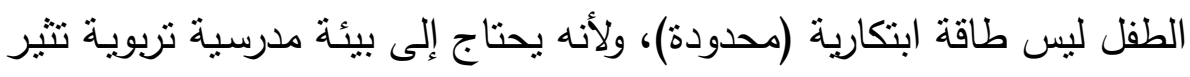

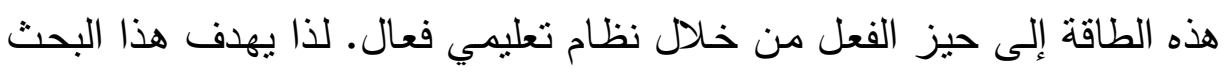

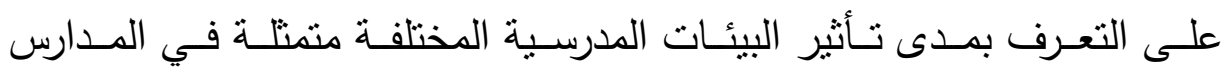

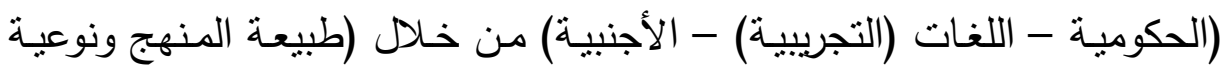
المدرسين والأنشطة المدرسية والإثراف الإداري) ومدى قدرته على تتمية جوانب البه الثخصية. أهداف الاراسة

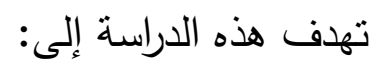
1- الكثـف عن الفروق بين البيئات المدرسية المختلفة (الحكوميـة - اللغـات (التجريبية) - الأجنبية) لدى التلاميذ.

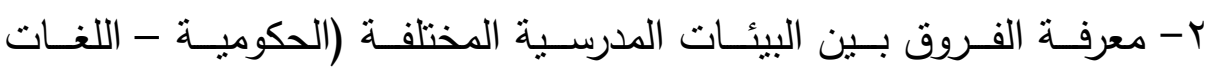
(التجريبية)- الأجنبية) على مفهوم الذات والابتكار للى التلاميذ. r- الكثف عن مدى اختلاف الفروق بين البيئات المدرسية المختلفة (الحكومية

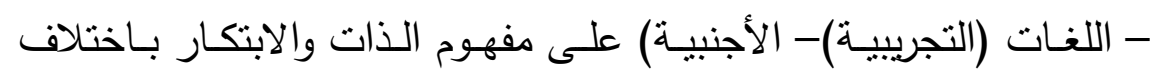

$$
\text { الجنس (الذكور - الإناث). }
$$

ع - قياس البيئة المدرسية وعمل مقياس لمفهوم الذات مما يساعد في قياس تلك الكان الظاهرة بالبيئة المحلية.

ه - حدود الاراسة

تم اختيار عينة عددها • ـ ب تلميذ من المدارس بدولة الكويت بالمرحلة المتوسطة

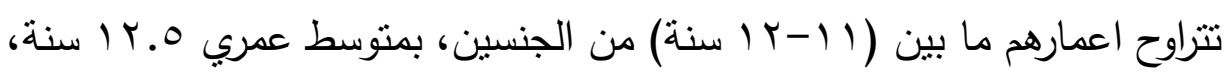
وقد روعي أن تكون من ذوي مسنوى (اجتماعي - اقتصادي) مرتفع. 
يستخدم في دراسات البيئة المدرسية مفاهيم عديدة منتوعة منل: مفهوم المناخ

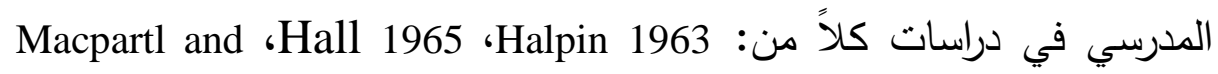
Celeney 1982، March 1982، Epston 1975 حطب ra19 أما الموقف المدرسي كان في دراسات كلاً من: سيد عثمان

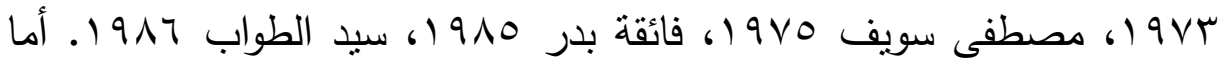

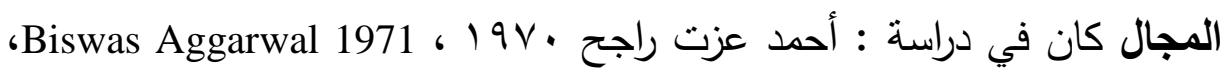

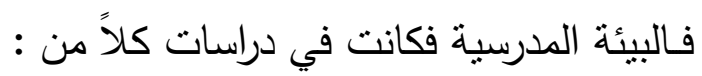

Harris ، Agenw 1982 ، Farser and Relout 1980 1987، عبد الهادي السعيد عبده 1919 \& Others 1995 حدد بعض الباحثين هذه البيئة التي يتوافر بها العوامل الميسرة للتفكير الابتكاري

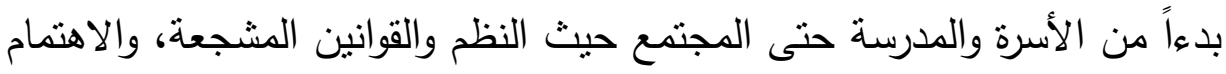
وتشجيع جميع أنواع الابتكارات والمواهب.(http://www.baaloria.com)

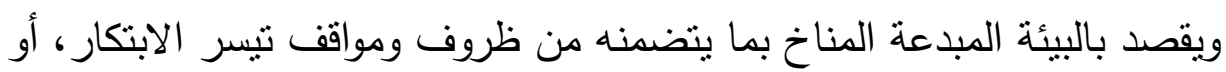
تحول دون إطلاق طاقات المتعلم الابتكارية. لذا سوف تعرف الباحثة البيئة المدرسية (المفتوحة- المغلقة) تعريفاً إجرائيا بما

البيئة المدرسية المفتوحة: Open Environment School هي البيئة المدرسية التي تتيح اكتثـاف قدرات الطفل وتتمى طاقاته الإبداعية

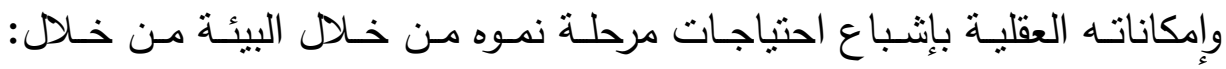

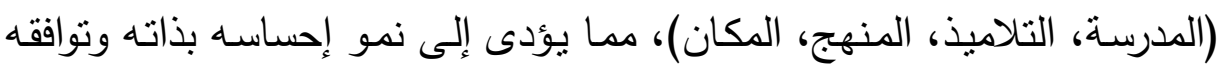

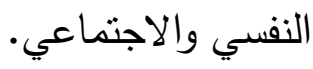


البيئة المدرسية المغلقة: Close Environment School هي البيئة المدرسية التي تعوق انطلاق قدرات وطاقاته الإبداعية المختلفة بعدم

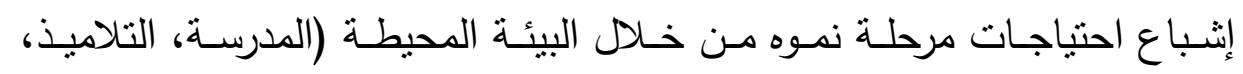

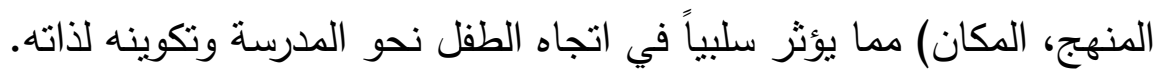
ثانياً: التفكير الابتكاري: Creative Thinking تعددت وتتوعت التعـاريف المختلفة التي تتاولت مفهوم الابتكار وذلك تبعـاً

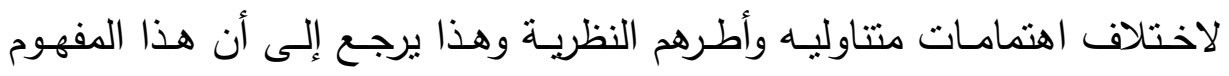

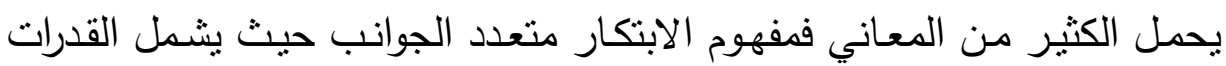
الابتكارية المساهمة في السلوك الابتكاري، وسمات الثخصية التي تساعد على الثى

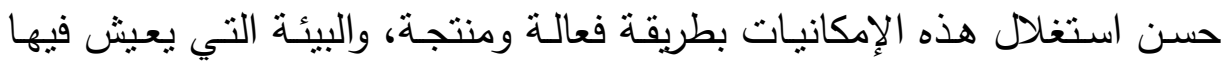
وتتفاعل مع الثخص المبتكر التي قد تمنعه من فرص ممارسة هذه الإمكانيات. الابتكار هو إيجاد شئ والكثف عن علاقته ووظائف جديدة.(عماد بدران عبد القادر ، (r) (r...) وتذهب مدرسة الجشتالت Gestalt في علم النفس إلى أن المبدع الموهوب هو ذلك الفرد القادر على إعادة دمج المعارف والأفكار بشكل جديد. (hhtp://www.elssafa.com)

يعرف جليفورد Guliford بأنه عملية عقلية معرفية أو نمط من التفكير التباعدي يتصف بالطلاقة والمرونة والأصالة والحساسية للمشكلات وينتج عنه ناته ناتجاً

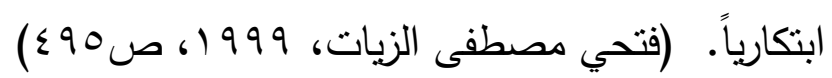

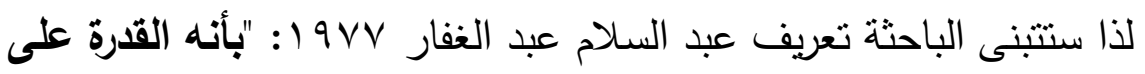
التعبير عـن الأفكـار والحــافز دون كـف ودون خـوف مـن سـخرية الآخـرين والوصول إلى مستوى مناسب من تحقيق الأت ". 
مكونات التفكير الابتكاري:

1-الأصالة: هي قدرة الطفل على تكوين علاقة جديدة بين الخبرات السابقة بحيث ينظمها في صور وأنشكال لا خبرة للطفل فيها من قبل. r-الطلاقة: هي قدرة الطفل على إنتاج أفكار غير شائعة. r-المرونة: هي قدرة الطفل على إنتاج أكبر عدد من الأفكار .

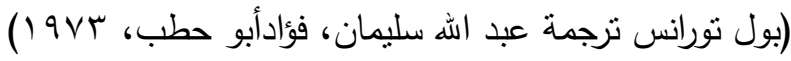

- مفهوم الأات: Self- Concept لقد زادت أهمية مفهوم الذات بوصفه وسيلة لدراسة السلوك الإنساني وفهمهـ ولقد تتوعت التعاريف التي تتاولت هذا المفهوم منها : على سبيل المثال تعريف Brokover and Others 1964 ، Rogers 1960

. Fames 1980، १ 9 V

تعرف الباحثة مفهوم الذات تعريفاً إجرائياً بأنه " عبارة عن تتظيم الخبرات التي يمر بها الفرد طوال حياته وفكرة الفرد عن ذاته، ويتأثز بالظروف البيئية والاجتماعية التي تحيط به.

\section{النظريات النفسية التي تتنازل العلاقة بين الفرد والبيئة} ا-نظرية الثخصية ونموذج البيئة لهولاند Holland:

يفترض هولاند أن أنماط الثخصية التي تميز الأفراد يقابلها نمـاذج بيئيسة وفي حالـة التتاسـق بـين نمط الثخصية للفرد ونمـوذج البيئة المنـاظرة تحقق الحاجات والأهداف ويكون الإشباع والتوافق والعكس في حالة عدم التناسق بين الثخصية والبيئة يكون عدم الإثباع. (Holland ,1959, p. 35-39) r- نظرية ستيرن Stern (للحاجة - الضغط): يفترض ستيرن أن ضغوط البيئة المدرسية تحدد سلوك التلاميذ، أما تيسر

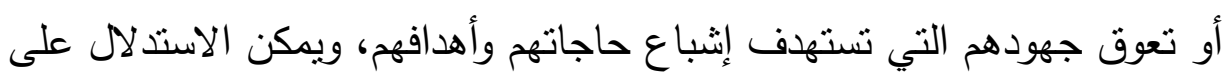

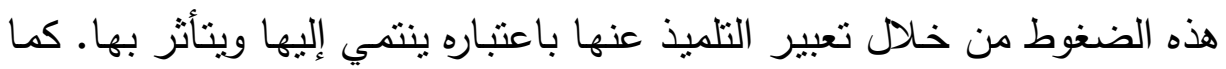


أن الضـغوط الفرديـة تعبر عن رأى الفرد بالأحداث والمحبط الذي يعيش فيـه ويمكن عليها من خلال الأفراد الذين ينتمون إليها.(Wilsh, 1975, P. 80-105)

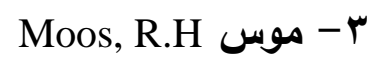

يؤكد موس على أهمية البيئة في تشكيل السلوك، ويرى في دراسته للبيئة الاجتماعية، أنه لابد من تحديد مفهوم المكان التربوي حيث أن الأماكن التربوية لئه

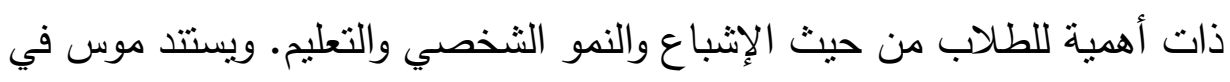
تصوره للبيئة الاجتماعية على المبادئ الآتية:

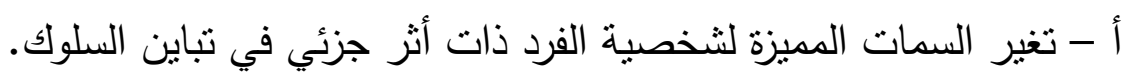

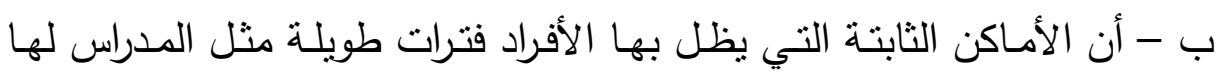

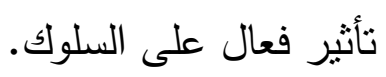
ج - تغير الإطار البيئوي الاجتماعي ذات تأثثير على سلوك واتجاهات وإنجازات الطلاب، ومفهوم ذاته. (Wilsh 1975, P. 103)

الاراسات (لسابقة:

تتاولت الدراسات العلاقة بين المتغيرات البيئية المدرسية والقدرة على التفكير

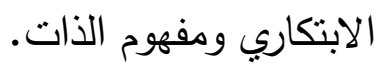
1-دراسـة 1972 بعنوان: Structure and Creativity is Weaver Early Childhood Education"

اهتمت هذه الدراسة بدور اللعب التمثيلي الابتكاري ، لدى الأطفال عمر

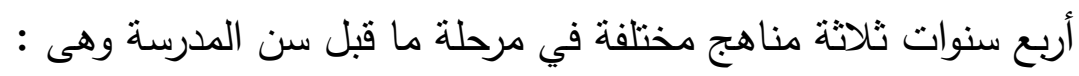

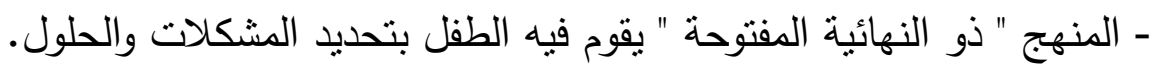
- أما منهج مونتيسورى Montessori يحدد فيه الطفل المشكلات، اما الحلول فتحددها المواد التعليمية. - منهج (بزاتير إنجلمان) يحدد المعلم مشكلات هذا المنهج وحلولها عينة عددها

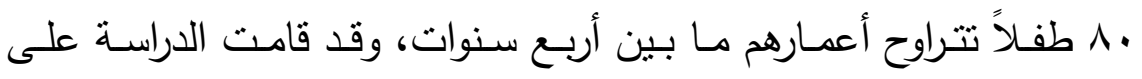

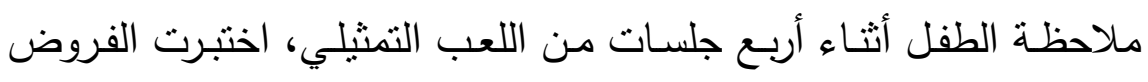
r 
باستخدام تحليل التباين وكان أهم نتائجها أن هناك علاقة ارتباطية موجبة

$$
\text { بين طبيعة المنهج والابتكار لدى الأطفال. }
$$

"A Study of the 1972 Buranajot عنـوس بورانـاجوتى relationship between the attitude teachers of Elementary

School with their Student Creativity"

وكانت تهدف إلى معرفة قدرة التلاميذ على التفكير الابتكاري واتجاهات المعلمين

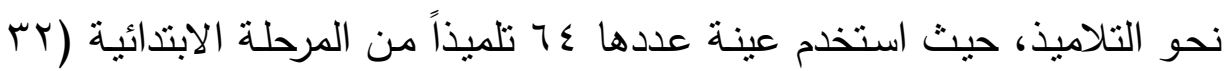

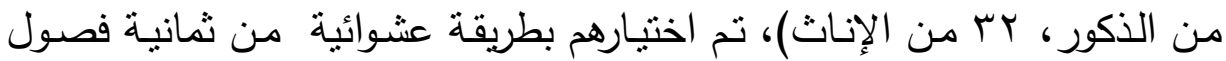
دراسية، وقد أسفرت النتائج عن وجود علاقة موجبـة بين القدرة على التقكير الابتكاري واتجاهات المعلمين نحو التلاميذ التي تتسم بالديمقراطية والتقبل لصالح

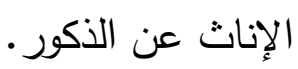

r-أما 1972 قام بلراسـة بعنوان: A Study of relationship between teacher educational attitude and action of student creative behavior and student creative potential and preference for creative behavior"

حيث قام بدراسـة العلاقـة بين قدرة التلاميذ على التفكير الابتكاري واتجاهـات

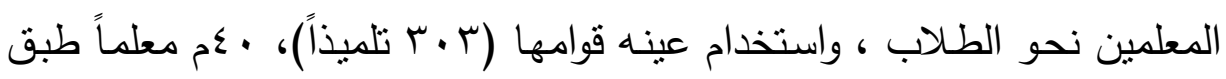
على التلاميذ اختبار تورانس للقدرة على التفكير الابتكاري، وقد أسفرت النتائج

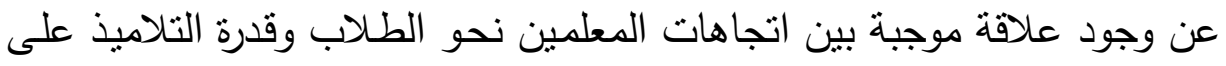
التفكير الابتكـاري بالإضـافة إلى المـهـج المعدل ، والمجموعـة الثانيـة المـنهج

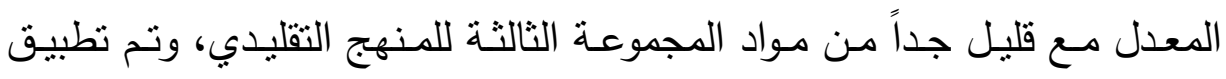

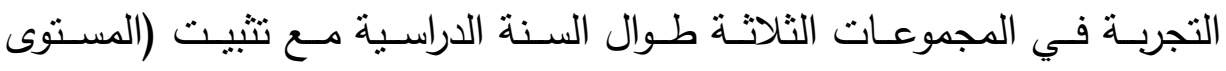
الاجتماعي والاقتصـادي - سن الطفل) وقد أسفرت النتائج عن تفوق المجموعة الأولى ، والثانية عن المجمعة الثالثة في التحصيل الدراسي والاستعداد للابتكار . ع -أما 1974 Piper, Ramey بدراسـة بعنوان: Creativity in Open and Traditional Classrooms" 
وتهدف إلى العلاقة بين قدرة التلاميذ على التفكير الابتكاري واتجاهات إدارة

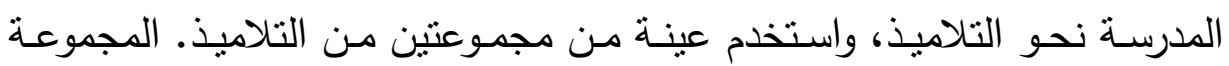

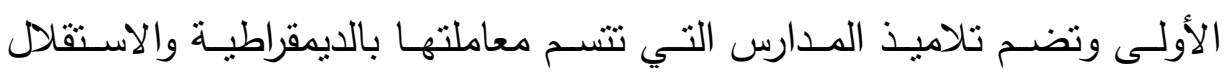

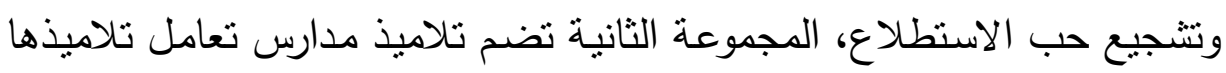
بطريقة تتسم بالضـغوط الثديدة والطاعة، ومن النتائج التي توصل إليها وجود

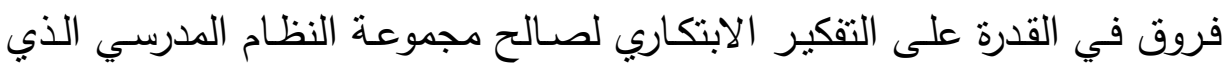
يتسم بالديمقراطية والاستقلال وتشجيع حب الاستطلاع.

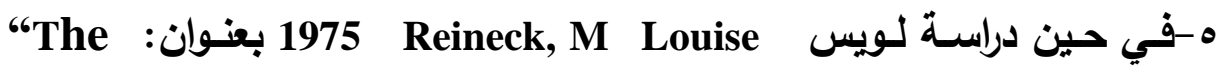
effectiveness of Creative, Free Play Program for Kindergarten Children" وكانت تهدف للتحقق من أن أطفال الحضانة يفكرون ويكتسبون قدراً من المهارات الابتكارية المتتوعة نتيجة للمنهج المعدل، لقد تم تعديل المنهج التقليدي لدور الحضانة بحيث يستبعد فيه كل الموارد والوسائل التعليمية ويستبدل برنامجاً

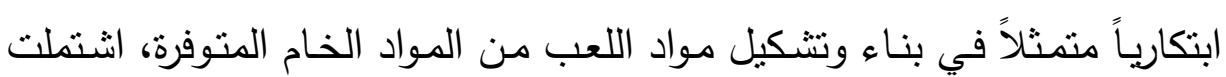

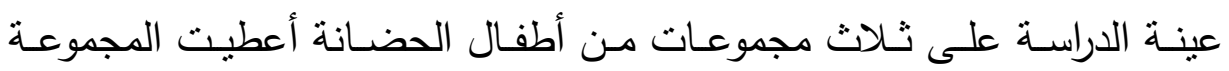
الأولى تشكيلة متتوعة من مواد اللعب.

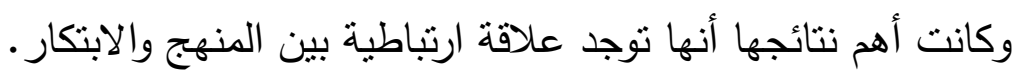
צ-دراسـة 1975 تستهوف دراسـة بعنوان: Predicting Learning Environments from teacher and Student Personality" وتستهدف دراسة أثر البيئة المفتوحة من حجرة الدراسة على تفاعل سمات التلاميذ

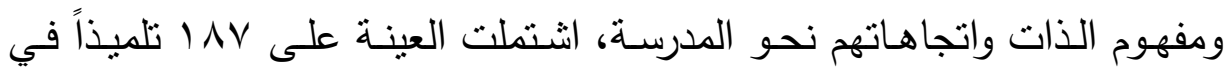
خمسة فصول. طبق عليهم استبيان الثخصية للأطفال، مقياس الاتجاه نحو وقد كثفت النتائج أن تلاميذ حجرات الدراسـة الأقل انفتاحاً يظهرون اتجاهـاً إيجابياً

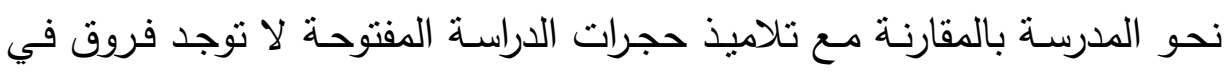


اتجاهات الذكور والإناث نحو المدرسة ويرتبط مفهوم الذات ارتباطاً إيجابياً بقدرات التلاميذ. V-دراسة فائقة محمد بلدر ه19 19 بعنوان: "دراسـة خصائص البيئة المدرسية والابتكار لاى المدارس الابتدائية"

وتهدف إلى دراسـة خصـائص البيئة المدرسية والابتكار في المدرسـة الابتدائية. وشملت العينة ـ . 1 تلميذاً طبق عليهم مقياس خصائص البيئة المدرسة واختبار تورانس وأسفرت النتائج أن هناك فروق دالة في أبعاد التفكير الابتكاري لصالح الصف السادس في البيئة الابتكارية.

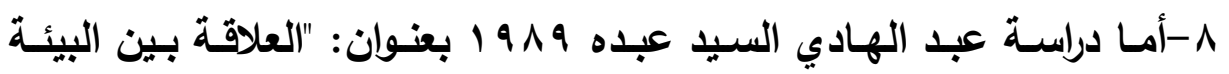
المدرسبة والأكاء لاى الطقل"

كانت تهدف إلى دراسـة العلاقة بين البيئة المدرسية والذكاء بالحكم الخلقي عند

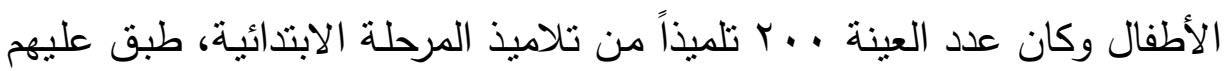

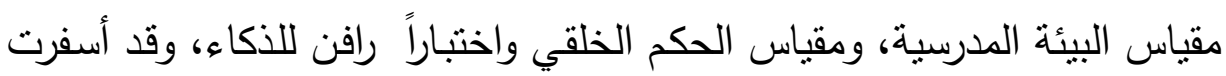

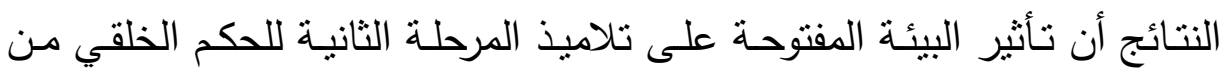
العينة أكبر من تأثنير البيئة المدرسية المغلقة على تلاميذ المرحلة الثالثة للحكم الخلقي من العينة أكبر من تأثير البيئة المدرسية المفتوحة. 9-قام مجدي عبد الكريم 1991 باراسة بعنوان: "مدى تفاعلية عاملية لمفهوم

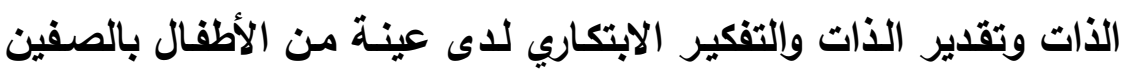

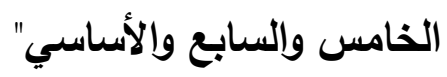
تهدف الدراسة إلى الكثف عن الفروق بين الأطفال المبتكرين في مكونات كل من نقدير الذات ومفهوم الذات والكثف عن العلاقة بين مكونات القدرة الابتكارية

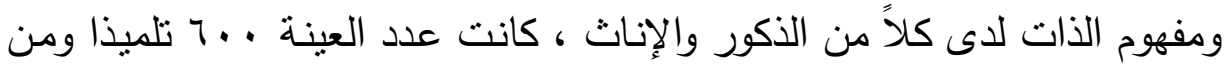

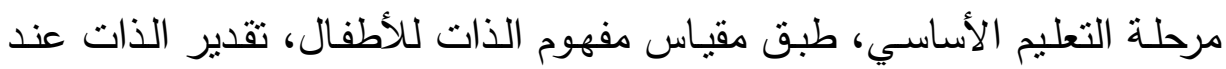
الأطفال (لكوبر سميث - مقياس إبراهام للتفكير الابتكاري) وكان أهم نتائجها 


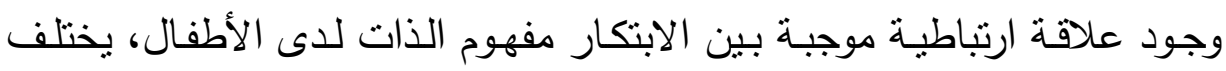
مفهوم الذات لدى الذكور عن الإناث لصالح الإناث.

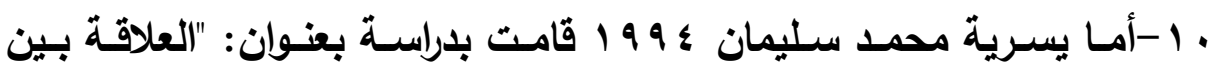

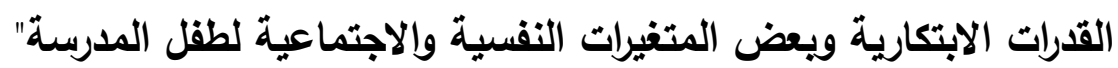
كانت تهدف للتعرف على مدى تأثثر كل من البيئة والقدرات الابتكارية لتلاميذ

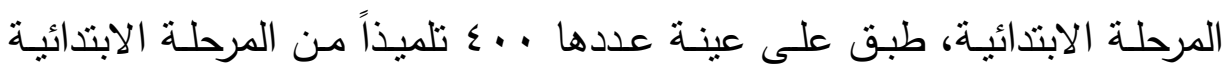
الريف والحضـر، استخدم المقاييس الآتية (الذكاء المصـور، التقكير الابتكاري

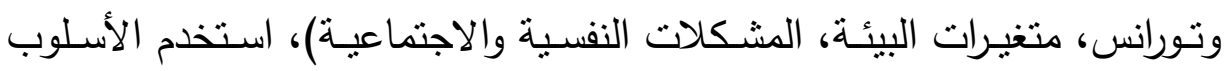

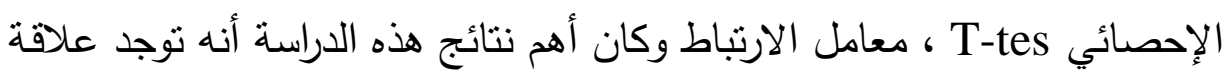

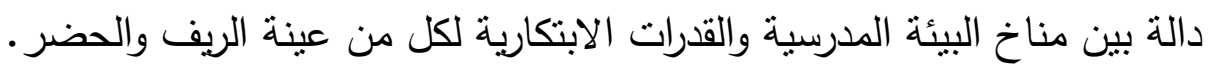
ا-قام 2000 David Herbert بدراسـة بعنوان: School Choice in the teachers Gatekeepers of an Uneven Local Environment Head playing Field" وكانت تهدف إلى التعرف على البيئة المغلقة في المدرسـة وأثرهـا على مفهوم

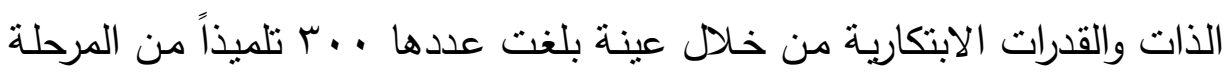
الابتدائية مقياس البيئة المدرسية ومفهوم الذات والابتكارية وجد إن هنالك علاقة ارتباطية دالة بين البيئة المدرسية ومفهوم الذات والقدرات الابتكارية للتناميذ. rامقام 2002 Petkus, Ed. بدراسـة بعنوان: The Creative Identity Creative Behavior from the Symbolic Interactions is Perspective" وكانت تهدف للتعرف على السلوك الابتكاري من خلال البيئة المدرسية ومكوناته

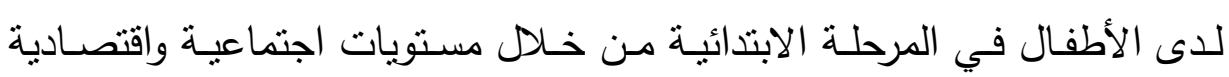

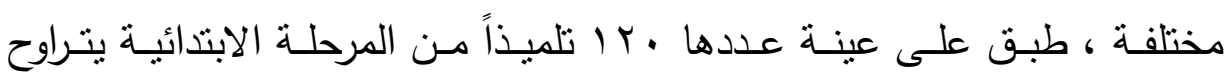

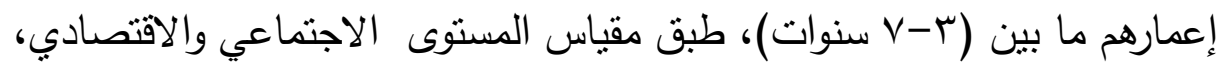

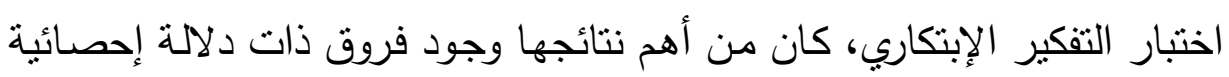

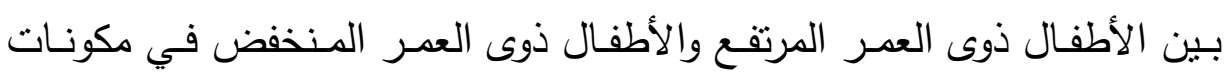
ITV 
القدرة الابتكاريـة : (الحساسية للمشكلات، الطلاقـة، الأصـالة، المرونـة لصـالح

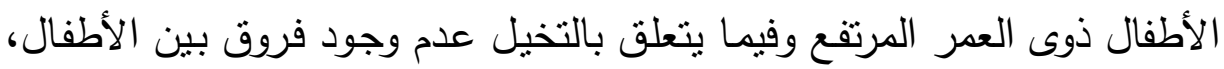
أن هناك علاقة دالة بين البيئة المدرسية وإحساس الطفل بذاته.

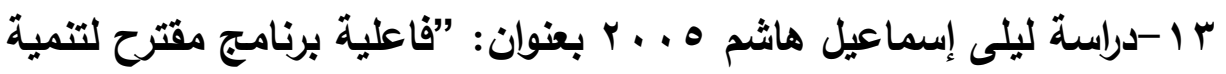
التفكير الابتكاري في اللغة الإنجليزية لاى طلبة الحلقة الثانية من التعليم<smiles>[Li][Mg][Mg]</smiles>

هدفت الدراسة إلى بنـاء برنامج مقترح لتتمية قدرات التفكير الابتكاري في اللغة

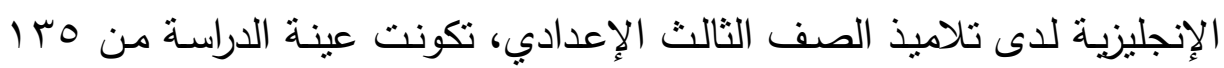

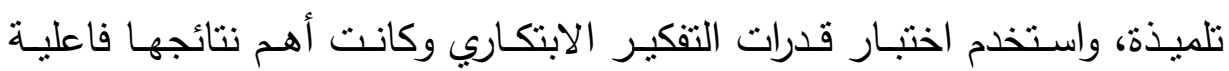
البرنامج مقترح في تتمية قدرات التفكير الابتكاري في اللغة الإنجليزية.

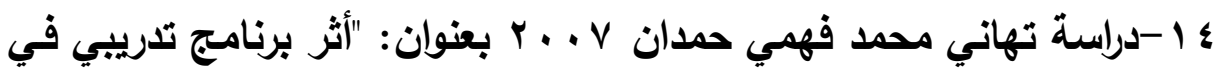
بعض الأنشطة الصيفية على تتمية التفكير الابتكاري للى تلاميذ الحلقة

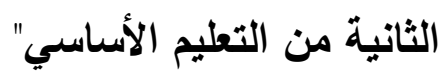

هدفت الدراسـة إلى الكثف عن أثر استخدام برنـامج في مجال بعض الأنشطة

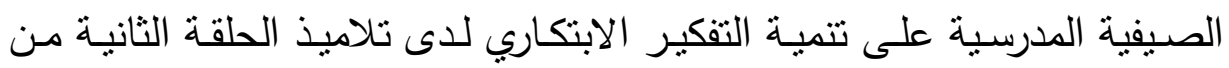
التعليم الأساسي. بلغت عينة الدراسة ـ ـ ا تلميذ، استخدمت الباحثة اختبار القدرة على التفكير الابتكاري وأسفرت النتائج عن فاعلية البرنامج في مجال الأنشطة

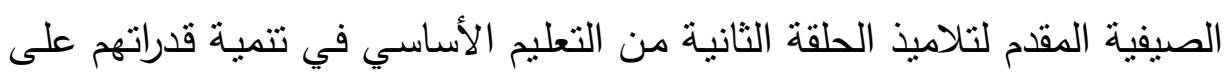
التقكير الابتكاري. ه - قام هواتج وفريسير Huang \& Fraser 2014 براسـة بعنوان: "لبيئة المدرسية وأثرها في أداء المعلمين" وهدفت الدراسة إلى التعرف على أثر البيئة المدرسية في أداء المعلمين، وتقديم البيئة المدرسية والتعرف على الاختلاف مابين توقعات معلمي ومعلمات العلوم

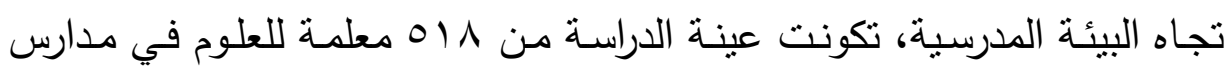


الثانويـة في تـايوان. وتم اسـتخدام الاستبانة كأداة لجمـع البيانـات. وكانت أهم

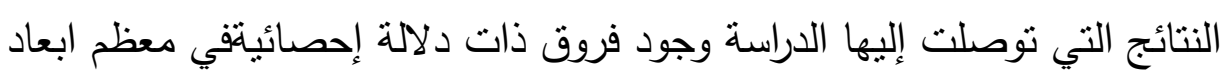
البيئة المدرسية تعزي إلى نوع الجنس. 7 1أمسا هوانج وإكسمان Huang \& Waxman 2015 بدراسـة بعنوان: "تقييم توقعات الطلبة في البيئة المدرسية"

هدفت الدراسة إلى تقييم توقعات الطلبة والمعلمين في بيئة المدرسة الثانوية وإيجاد

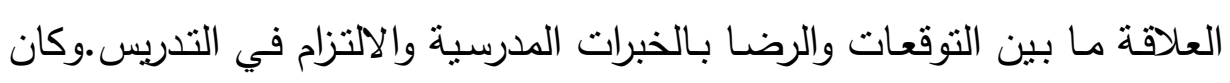
أهم النتائج أن البيئة المدرسية الداعمة مهمة لتمكين خبرات الطلبة التدريسية.

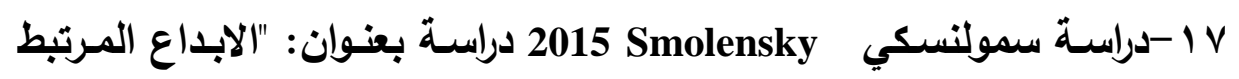

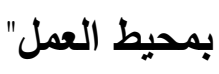

هدفت الدراسة إلى القيام بفصص الإبداع المرتبط بمحيط العمل والاتجاهات

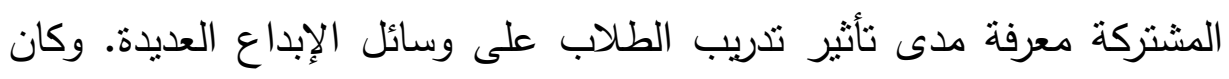

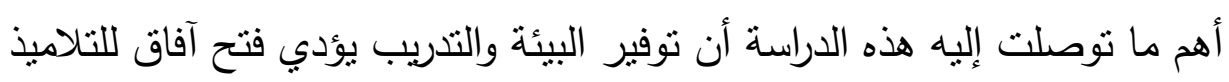

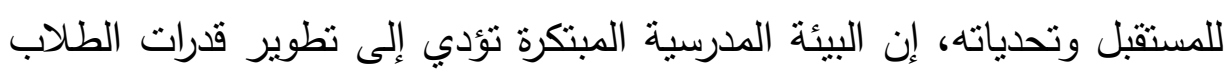
على التقكير الإبداعي وحل المشاكل بطريقة ابتكارية من خلال استعراض الاراسات السابقة نلاحظ ما يلي:

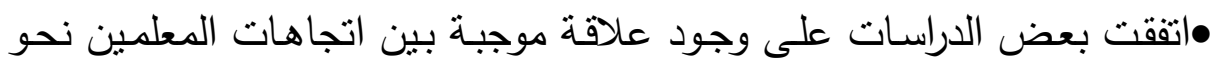

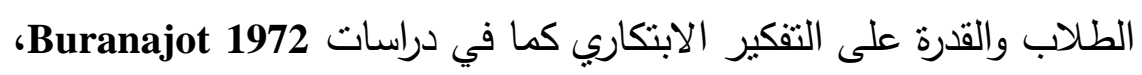
Ray 1974 , Ramey 1974, Piper Huang \& Waxman 2015 •أكدت الدراسـات وجود علاقـة بين نوعيـة المنهج الدراسـي والقدرات الابتكاريـة Reineck ،Jant Elizabath للتلاميذ كما في دراسة كلاً من: 1971

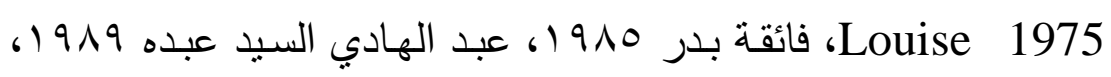
.Huang \& Fraser 2014 
•اتفقت الدراسات على وجود علاقة ارتباطية دالة بين البيئة المدرسية ومفهوم

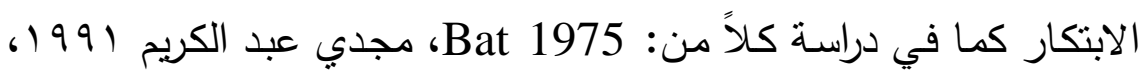

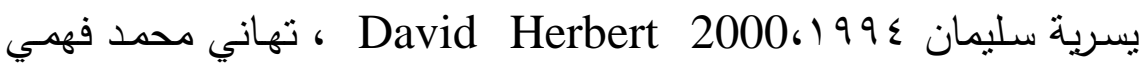

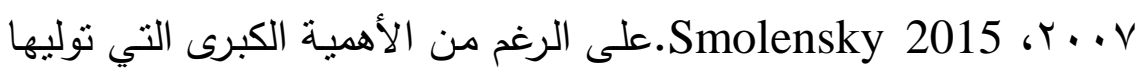

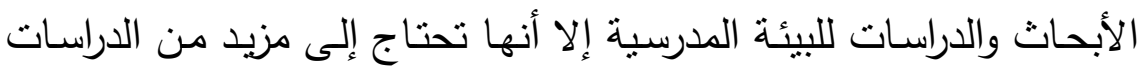

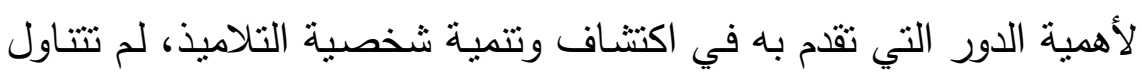

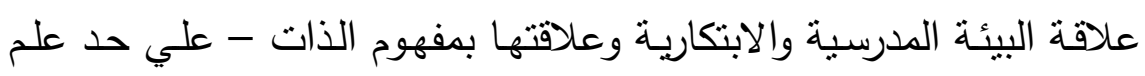
الباحثة - لذا ستحاول تتاولها بمزيد من الدراسة.

لذا ستحاول هذه الاراسة من الفروض الآتية:

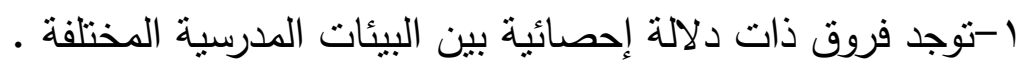
r-توجد فروق ذات دلالة إحصائية بين البيئات المدرسية ومفهوم الذات. r-ثوجد فروق ذات دلالة إحصائية بين البيئات المدرسية والابتكارية. ع-يختلف مفهوم الذات لدى الجنسين باختلاف البيئات المدرسية. 0-يختلف مفهوم الابتكار لاى الجنسين باختلاف البيئات المدرسية. 7- يختلف مفهوم الذات والابتكار باختلاف البيئات المدرسية.

وإجراءات الدراسة

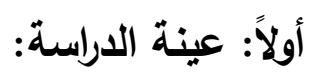

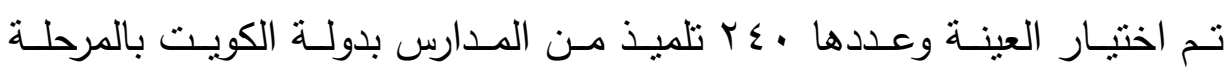

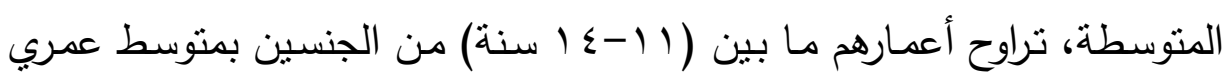

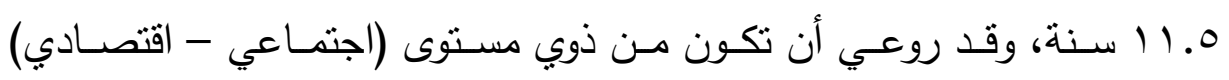

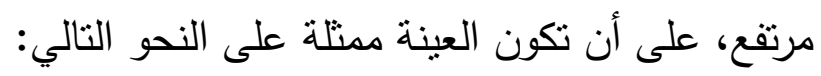

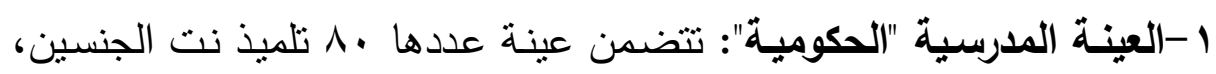
اختيرت من خمس مدارس حكومية تتصف البيئة المدرسية بما يأني: -

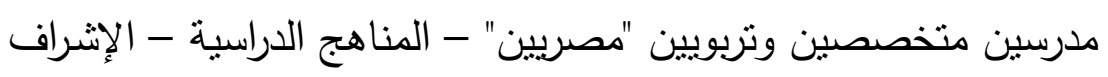


الإداري - التوجيـه الفنـي "تابع لنظـام التعليم الكويتي"- اللغــة الدراسبية "العربية" ماعدا اللغة الإنجليزية).

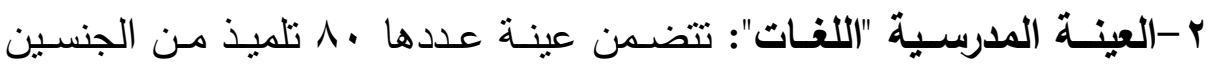

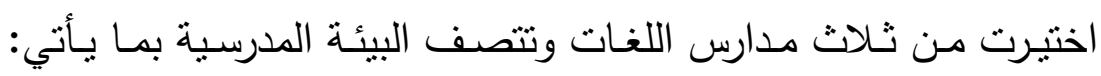
(مدرسين متخصصين - غير تربويين - مصريين وأجانب - مناهج دراسية

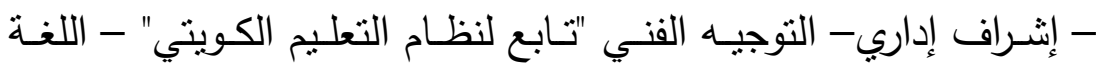

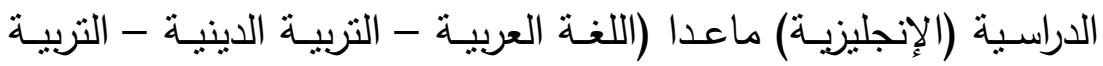
الاجتماعية).

ب-عينة المدارس الأجنبيةة: تتضمن عينة عددها ــ ثلميذ من الجنسين اختيرت

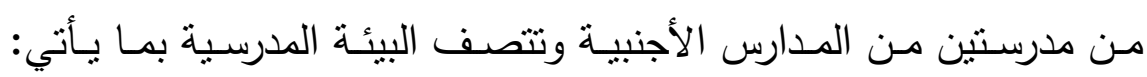
(مدرسـين "متخصصـين وتربـويين"، المنـاهج الدراسـية، الإثــراف الإداري،

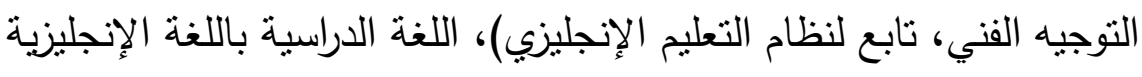

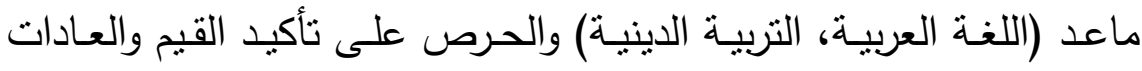
الثرقية. الأكاء:

أظهرت العديد مـن الدراسـات وجـود علاقـة ارتباطيـة موجبـة دالـة بين الابتكـار

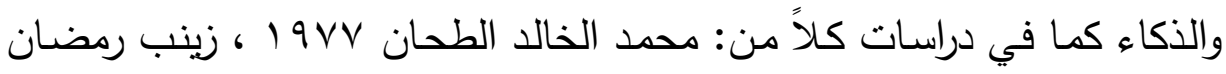

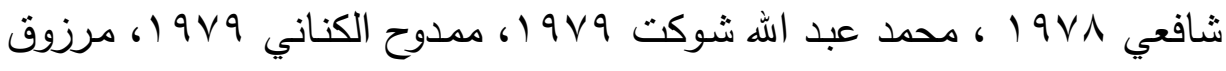

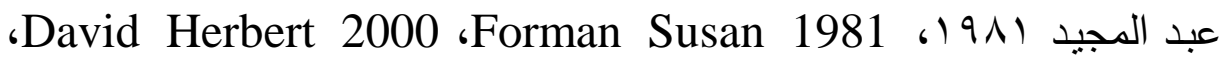

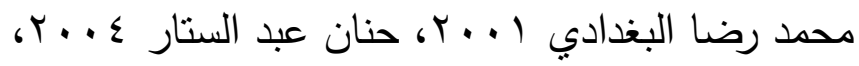

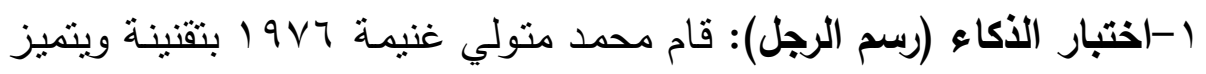

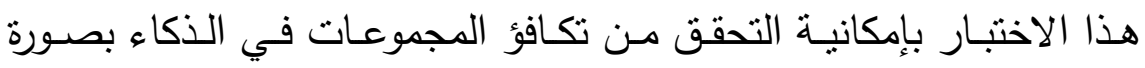

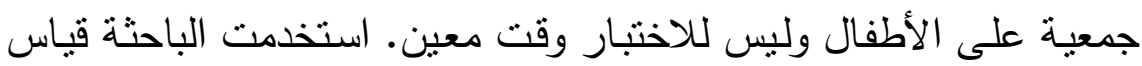
مستوى ذكاء الأطفال لاستبعاد التلاميذ الذين يقل مستوى ذكائهم عن الموقع 
لتحقيق درجة التشابه والتجانس بين أفراد عينة البحث لما أظهرته العديد من الدراسات بوجود علاقة ارتباطية دالة بين الابتكار والذكاء في دراسات عديدة

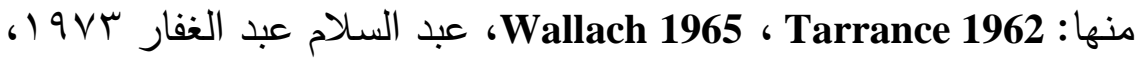
Karen ، Rachelle 1977

Meador قامــت الباحثـة باســتخدام (t-Test) لحســاب قيمـة (ت) ودلالتهـا

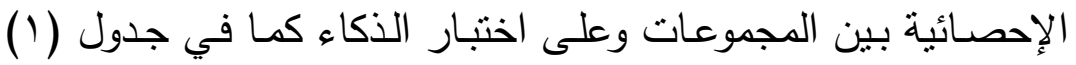

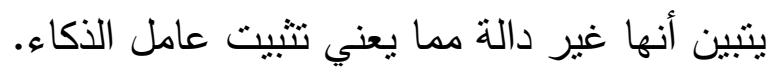
جدول (1) المتوسط والانحراف المعياري واختبار (ت) لعينة الدراسة على دلى البيئات المدرسية المختلفة لمتغير الأكاء

\begin{tabular}{|c|c|c|c|c|}
\hline مستوى الدلالة & قيمة ت & الإنحراف المعياري & المتوسط & البيئة المدرسية \\
\hline \multirow{3}{*}{ 等: } & $.0 \mathrm{~V}$ & $0.0 \mathrm{~V}$ & $9 \wedge . \varepsilon \varepsilon$ & البيئة الددرسية" \\
\hline & $1 . .1$ & $7 . .1$ & १९.५ & البيئة المدرسية "الغات" \\
\hline & $1.1 \%$ & $\varepsilon . .1$ & AT.1T & البيئة الددرسية الحكومية \\
\hline
\end{tabular}

- تم حساب تصحيح اختبار الذكاء بحساب معامل الارتباط بين تقديرات مصحح

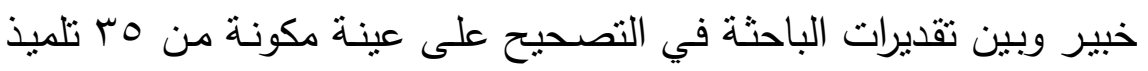

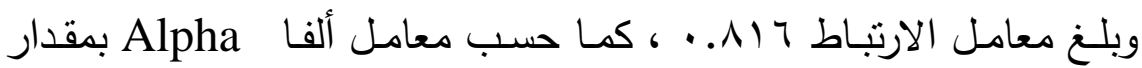
$\cdot .91 r$

الخصائص السيكومترية

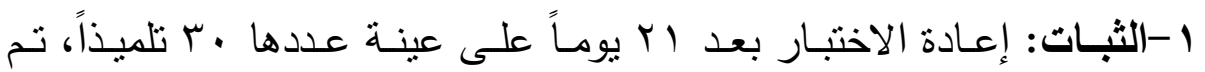

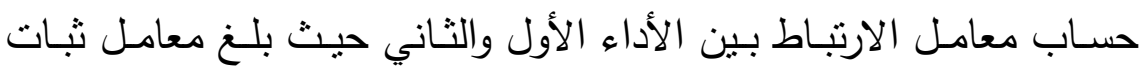

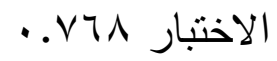

ץ-الصدق: تم قياس درجات اختبار جودانف واختبار الذكاء المعروف وتراوح معامل الارتباط بين الاختبارين (7 . . - -9. . ) ). المستوى الاجتماعي الاثتصادي (إعداد الباحثة) 
اهتمـت الباحثنة بـأن يكون أفراد العينـة النهائيسة لبحثنهـا في ظـروف اجتماعيـة

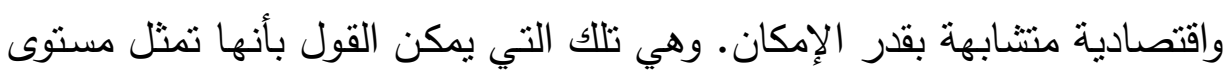

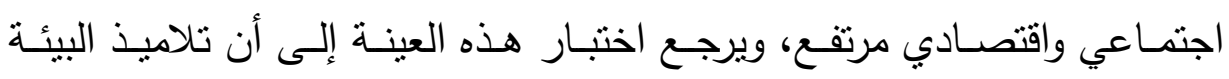

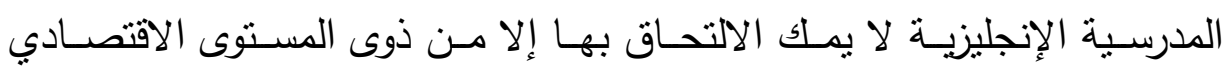
والاجتماعي المرتفع. كما أكدت العديد من الدراسـات وجود علاقة ارتباطية دالـة بين الابتكار

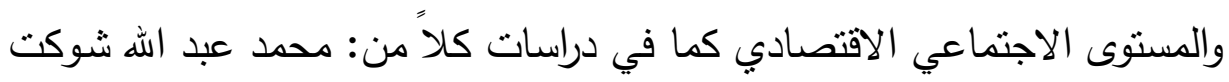

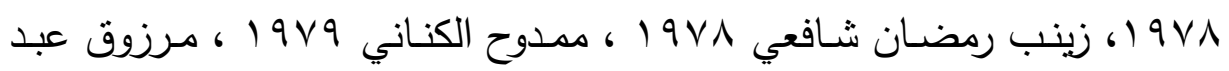
Perry, Chrisna المجيد 1919 192007 جدول (r)

يبين (t-Test) المستوى الاجتماعي والاقتصادي لعينة الدراسة

\begin{tabular}{|c|c|c|c|c|c|c|}
\hline مستوى الدلالة & قيمة ت & \multicolumn{2}{|c|}{ المستوى الاقتصادي } & \multicolumn{2}{|c|}{ المستوى الاجتماعى } & البيئة المدرسية \\
\hline \multirow{3}{*}{ غير دالة } & 1.91 & 1.91 & rr... & r.IV & rr.q. & البيئة المدرسية" \\
\hline & 更 & 1.0. & 10.04 & 1.00 & $10 . V V$ & "البيئة المدرسية \\
\hline & 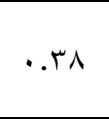 & $1 . \leqslant 1$ & $|r . T|$ & r..r & $|r . \Lambda|$ & البيئة المدرسية \\
\hline
\end{tabular}

استخدم (t-Test) على العينة فكانت غير دالة مما يدل على تثيبت عامل

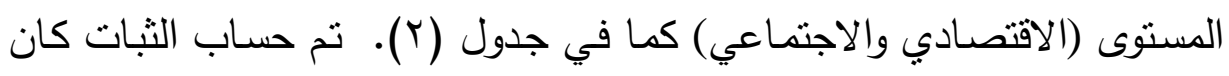
مقداره rی... ، الصدق كان مقداره 19.

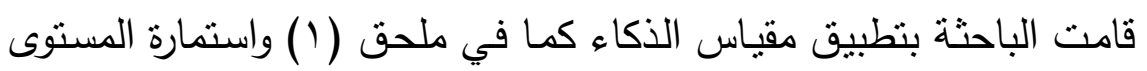

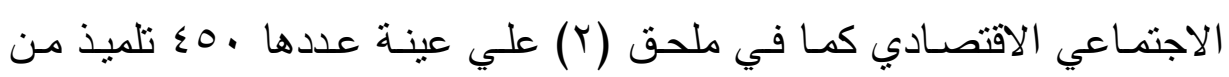

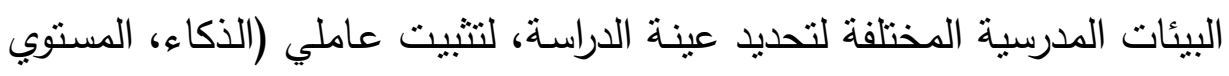
الاجتماعي، الاقتصادي). 
ثانياً: أدوات الدراسة

1-مقياس التفكير الابتكاري: Creative thinking

اختبار التفكير الابتكاري من تأليف بول تورانس وترجمة عبد الله سليمان وفؤاد الادئ أبو حطب وهو من صورتين (أ، ب)، ويعتبر أنشطة الاختبار نموذجاً لعملية وتئة

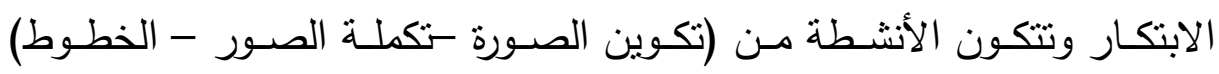

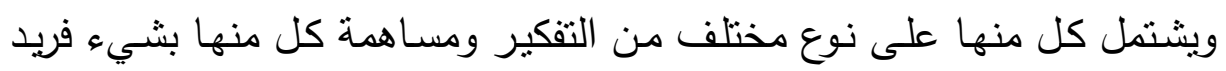

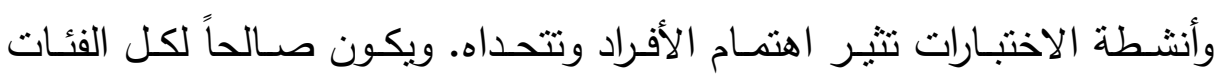

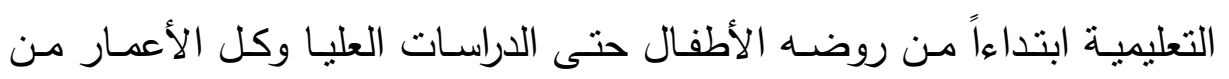
الجنسين.

أ-التصـيح: وفقاً لكراسـة التعليمات، هناك قواعد خاصـة بتصحيح كل نشـاط

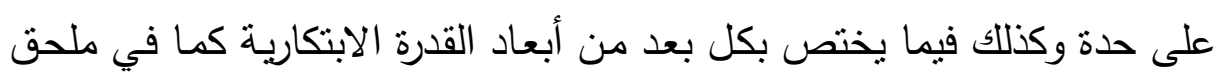

ب-الثبات: تم حسـاب الثبات الاختبار بطريقة "إعادة النطبيق" بفاصل زمني

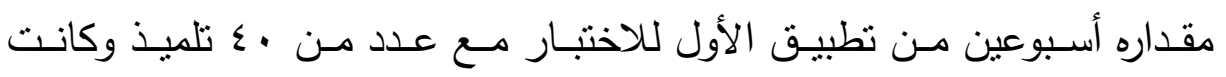

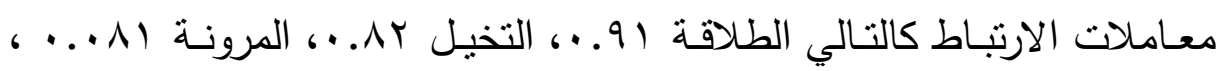

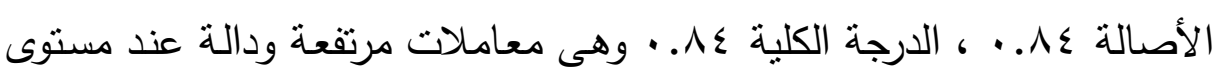

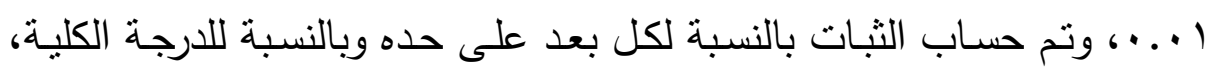

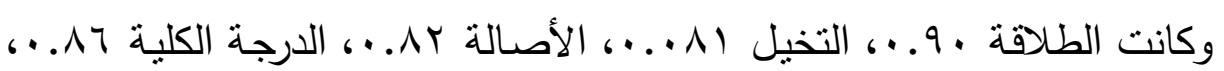
وهي معاملات ثبات عالية. ج-الصدق: تم حساب الصدق كالآتي: تبات عالهُ 1- المعامل الاتساق الداخلي:

قانت الثلاث، كذلك حساب معاملات الارتباط بين درجات الاختبار والدرجة

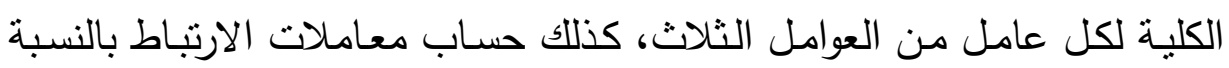




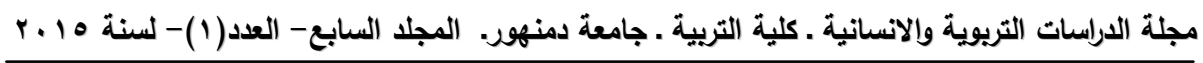

لكل بعد مـع الأبعاد الأخرى. وقد كانت المعاملات الناتجـة دالـة عند مستوى

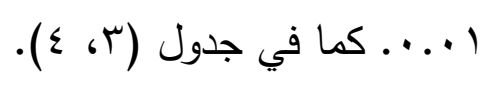

جدول (ץ): يبين مصفوف معاملات الارتباط للأبعاد لمقياس التفكير الابتكاري

\begin{tabular}{|c|c|c|c|}
\hline الأصالة & المرونة & الطلاقة & الأبعاد \\
\hline.$\wedge \varepsilon$ & $\therefore \vee \wedge$ & - & الطلاقة \\
\hline . .Ar & - & - & المرونة \\
\hline- & - & - & الأصالة \\
\hline
\end{tabular}

جدول (؛): يبين معامل الارتباط بين الدرجة الكلية وأبعاد اختبار التفكير

الابتكاري

\begin{tabular}{|c|c|c|c|}
\hline الأصالة & المرونة & الطلاقة & الارجة الكلية \\
\hline.$\wedge r$ & .97 & .10 & الدرجة \\
\hline
\end{tabular}

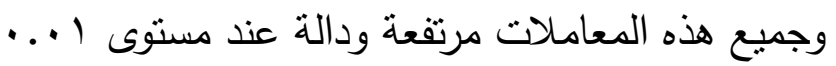

r - الصدق الأتي: قامت الباحثة بحساب الصدق الذاتي بالنسبة لكل قدرة

$$
\text { من قدرات التفكير الابتكاري وقد }
$$

حصل علي القيم التالية كما موضح بالجدول (0) (ه)

\begin{tabular}{|c|c|}
\hline معاملات الصدق & الأبعاد \\
\hline. .941 & الطلاقة \\
\hline$\therefore .9 \times 9$ & المرونة \\
\hline. .911 & الأصالة \\
\hline
\end{tabular}

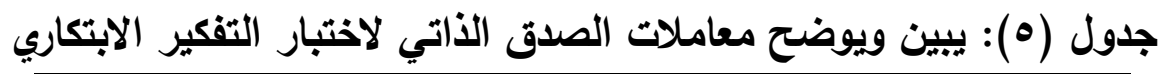

وتتثير حسابات الصدق والثبات لاختبار تورانس للتفكير الابتكاري الصورة ( أ ) إلى أن هذا الاختبار علي درجة عالية من الصدق والثنات.

r-مقياس مفهوم الذات: Self-Concept "إعداد الباحثة "

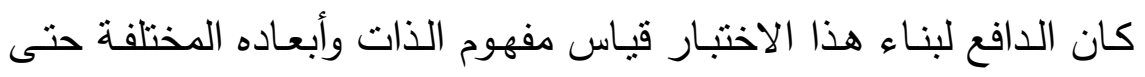
تتسـني دراسـة هـذا المفهوم دراسـة علميـة موضـوعية، وقـد مـر بنـاء الاختبـار

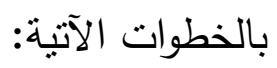


أ- استبيان استطلاعي مفتوح علي عينة من الأطفال عددها . 17 تلميذا

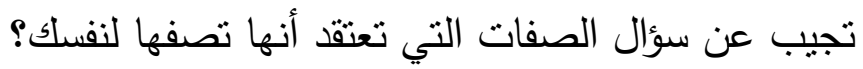

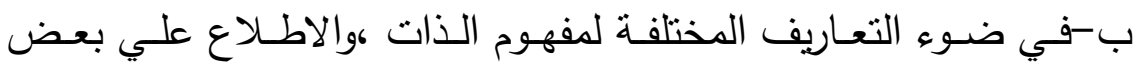

المقاييس التي تتاولت مفهوم الذات التي كان ومن أهمها اختبار مفهوم الذات

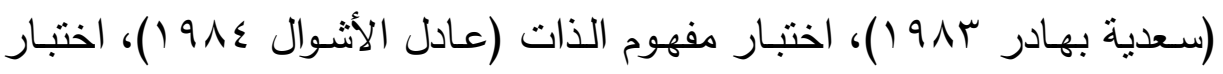

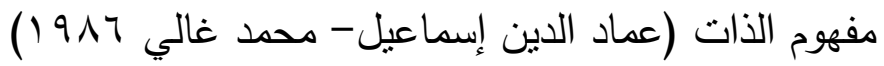

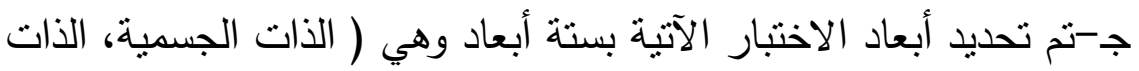

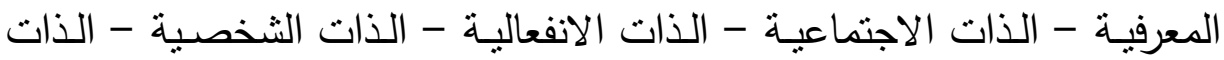

الأسـرية). وقد روعي أن تكون الأبعـاد مـن السـعة والثـمول حتي يمكن قدر

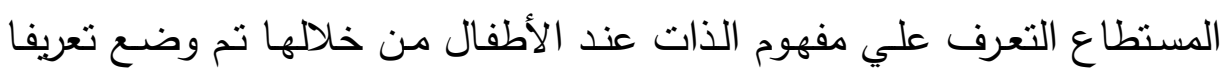
عاما لكل بعد من الأبعاد اعتمد عليه في تحديد وجمع عبارات كل بعد. وطبق

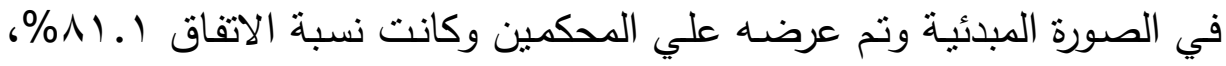
وتم تعديل وحذف العبارات التي اتفق عليها المحكمين وضع الاختبار في صورته

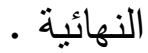

ا- طريقـة تقدير درجـات مقيـاس المفهوم الذات : عـرض المقيـاس في

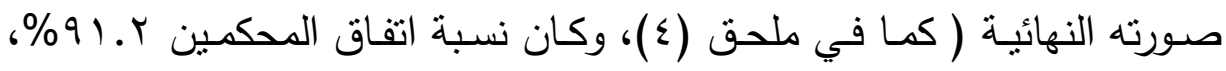

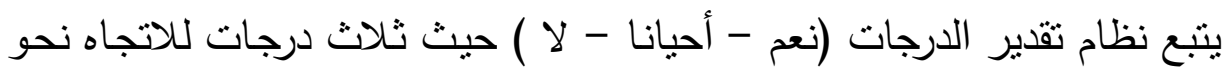
مفهوم ذات إيجابي، درجتين للاتجاه نحو مفهوم ذات إيجابي، درجتين للاتجاه نحو مفهوم ذات محايد ودرجة واحدة للاتجاه نحو مفهوم ذات سلبي.

الخصائص السيكومترية

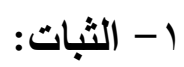

تم حساب ثنات المقياس بطريقتين كما يلي: أ - ثبات معامل - ألفا: تم تقدير ثبات المقياس بحساب قيمة - Cronbach-

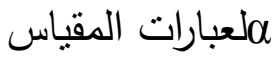




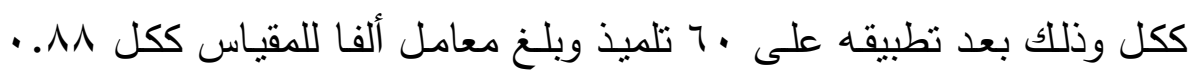
وهى قيمة مرتفعة تشير إلى الاتساق الداخلي والثبات المرتفع للمقياس.

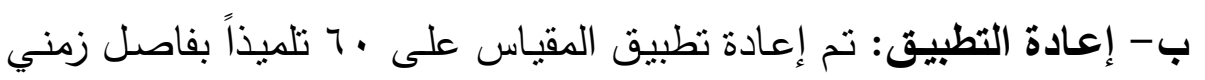

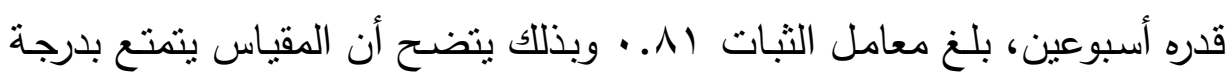
ثبات عالية.

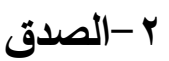

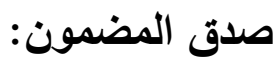
قامت الباحثة بعرض المقياس في صورته الأولية على مجموعة من المحكمين

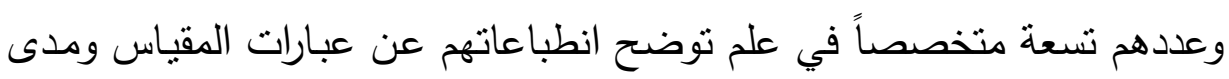

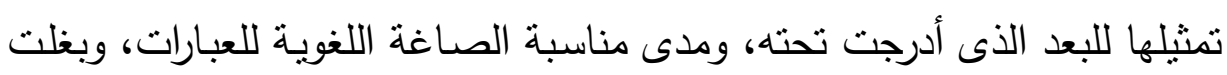

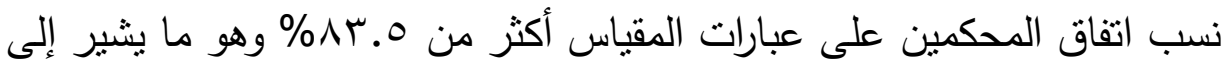
أن المقياس يتمتع بصدق مضمون مرتفع •

جدول (آ) تبين العبارات لكل بعد لمقياس مفهوم الأتات

\begin{tabular}{|c|c|}
\hline 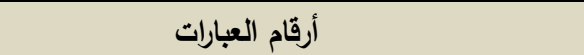 & 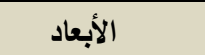 \\
\hline$O V-O Y-\varepsilon \Lambda-\varepsilon Y-Y V-Y r-1 \leqslant-V-1$ & الذات الجسمية الذية \\
\hline$\varepsilon r-\varepsilon 1-r q-r V-r r-r Y-q-10-\lambda-7$ & 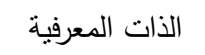 \\
\hline$\Upsilon 1-09-\varepsilon \cdot-r \wedge-r q-r \wedge-r q-r|-| r-q-0$ & الذات الاجتماعية \\
\hline $7 \cdot-\varepsilon q-r \leqslant-r r-r \cdot--Y \leqslant-r \cdot-19-1 V-r$ & 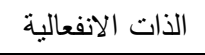 \\
\hline$Y Y-O \Lambda-O Y-\sum V-\varepsilon O-r\left|-Y_{0}-\right| \Lambda-1 \mid-1 \cdot-\varepsilon$ & الذات الثخصية \\
\hline $07-00-0 \leqslant-01-0 .-\varepsilon \tau-\varepsilon \leqslant-r_{0}-r_{q}-1 Y-r$ & 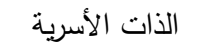 \\
\hline
\end{tabular}

r-بناء مقياس مستوى البيئة المدرسية: إعداد الباحثة حددت الباحثة أبعاد المقياس بمستوى البيئة المدرسية من خلاد دراسات عديدة منها فائقة محمد بدر 1910 ، عبد الهادي السيد عبده 919 19 (، سالم محمد سالم David Herbert 2000،Peter Kahn 1998 ، 199. -وضع المقياس في صورته المبدئية للتحكيم من (أساتذة متخصصين في مجال علم النفس) لتوضيح مدى تمثيل عبارات المقياس للبعد الذى يندرج تحته ITV 
ومدىى مناسبة للصياغة اللغويـة للعبـارات، وبلغت نسبة اتفاقهم تراوح مـا بـين

$$
\text { (\%N1.)-\%Vr.r) }
$$

من خلال التعريف الإجرائي للبيئة المدرسية في هذه الدراسة:

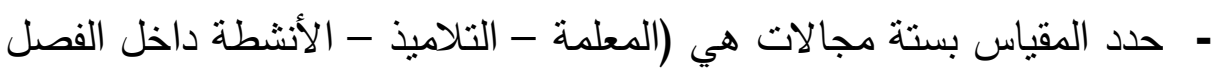

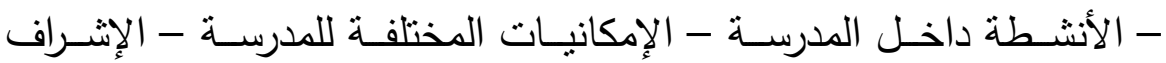
الإداري)، وضـع المقياس في صورته النهائية كما في ملحق (0) كان نسبة الإنهان

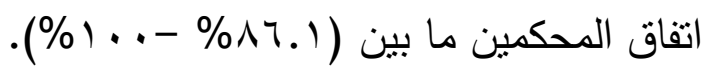

- استعانت الباحثة بفريق للتطبيق يتكون من (0 معيدين، 7 مدرسين مساعدين

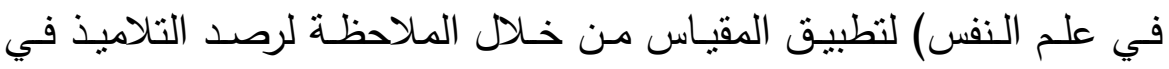
المدراس التي تم تحديدها لتكون عينة الدراسة.

\section{الخصائص السيكومترية}

1 - بات المقياس:

طريقة التجزئة النصفية لحساب معامل ثبات المقياس بطريقة سبيرمان على عينـة قوامها ، ـ تلميذاً كما في جدول (^) يتضـح أن معاملات الثبات لأبعاد

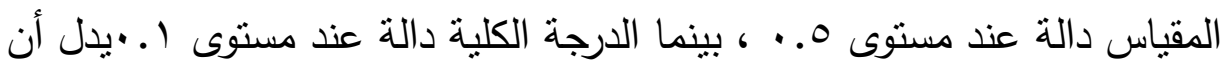
المقياس يتمتع بثبات عال.

جدول(^): يبين معاملات ثبات مقياس البيئة المدرسية بطريقة التجزئة

\begin{tabular}{|c|c|c|c|}
\hline مستوى الدالة & معامل الثبات & معامل الارتباط & أبعاد المقياس \\
\hline داله عند مستوى ه... & $.0 r$ &.$r v$ & المعلمة \\
\hline داله عند مستوى ه... &. $.0 \mathrm{~V}$ &..$\leqslant r$ & التلاميذ \\
\hline داله عند مستوى ه... &. .07 & $\because \varepsilon$. & الأنشطة داخل الفصل \\
\hline داله عند مستوى ه... & 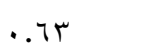 &..$\leqslant 0$ & الأنشطة داخل المدرسة \\
\hline داله عند مستوى ه... &. .01 &. r & الإمكانيات المختلفة للمدرسة \\
\hline داله عند مستوى ه .. & $.0 \leqslant$ & דו & الإثراف الإداري \\
\hline داله عند مستوى 1 ... &. $.7 \mathrm{~V}$ & $.0 r$ & الارجة الكلية للمقياس \\
\hline
\end{tabular}

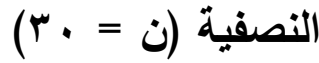

Doi: $10.12816 / 0034808$ 


$$
\text { r الصدق العاملي }
$$

قامت الباحثة بالتحليل العاملي للعينة الكلية وقد وجد عامل مشترك لجميع الأبعاد

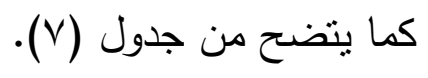

\begin{tabular}{|c|c|c|c|c|c|c|c|}
\hline المدرسية & الإثراف & اللإمكانيات & الأنثطة & الأنشطة & التلاميذ & المطلمة & الأبعاد \\
\hline .91 & . . &.$V Y$ &.$v r$ & .70 & $\cdot v \cdot$ &.$V 4$ & بالتعامل الأول \\
\hline
\end{tabular}

جدول (V): يبين التشعبات الدالة لأبعاد اختبار البيئة المدرسية بالعامل الأول

\section{للعينة الكلية}

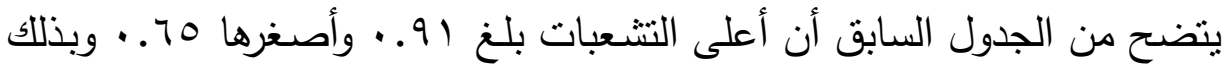

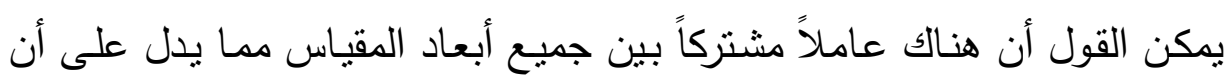
الاختبار على درجة كبيرة من الصدق العاملي.

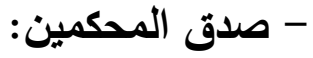
قامت الباحثة بعرض المقياس في صـورته النهائيسة على مجموعـة من

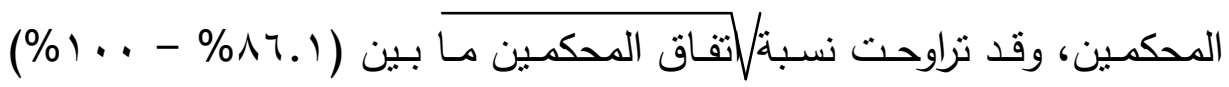

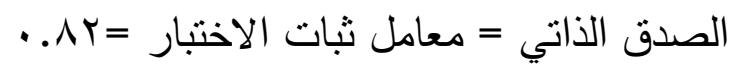
ع - بناء بطاقة الملاحظة: "إعداد الباحثة " اسـتخدمت الباحثنة الملاحظــة التـي تعتبـر مـن الأسـاليب الجيـدة لدراســة

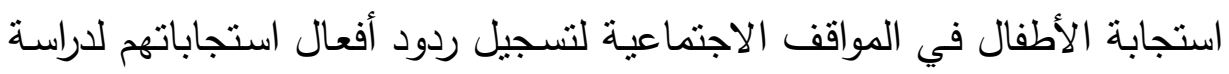
التفاعلات التي تجرى بين الأطفال والمدرسة وبين الأطفال بعضهم ببعض، لذللك

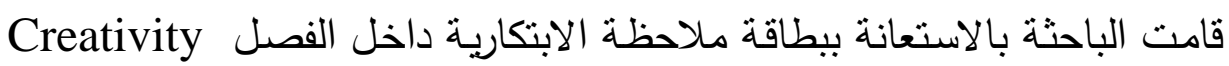
Denny, A. على النمط الذى وضعه Observation School Classrom Rusch 1974 وأخرون. تهدف هذه البطاقة إلى دراسة العلاقة وأسلوب المعلم في التدريس وابتكارية التلاميذ وتتقسم البطاقة إلى قسمين الأول للمدرسة والثاني 149 
للأطفال مدة البطاقـة خمسين دقيقة كمـا في ملحق (T) تسـل الملاحظـة كل دقيقتين.

\section{الخصائص السيكومترية}

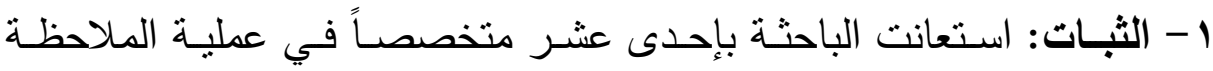

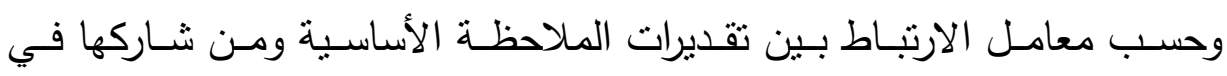
الملاحظة في مكونات بطاقة الملاحظة فكانت كلها دالة وتتراوح الدرجة الكلية ما

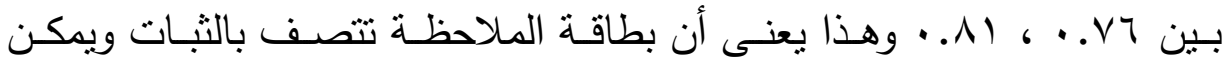

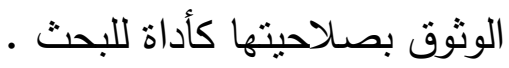
ץ- الصدق: حسب معامل الارتباط بين الدرجة الكلية ومكونات البطاقة لحساب

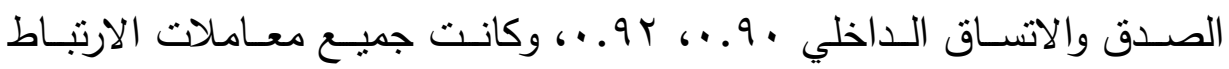

موجبة.

\section{المعالجة الإحصائية وتفسير النتائج}

قامت الباحثة باستخدام الأساليب الإحصائية الآتية: المتوسطات الحسابية ودلالة

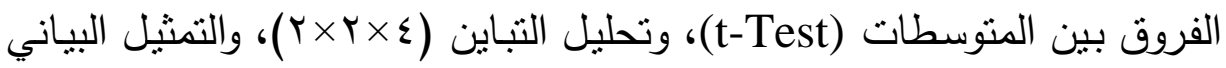

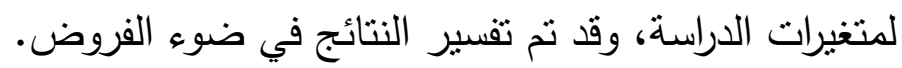

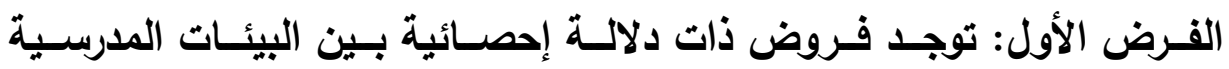
المختلفة لاى التلاميذ.

لتحقيق هذا الفرض حسب المتوسط الحسابي والانحراف المعياري كما في جدول (9) وتحليل التباين المزدوج (F-Test) كما في جدول (• (1) لأبعاد مقياس البيئة المدرسية على البيئات المدرسية المختلفة (الأجنبية - اللغات - الحكومية). جدول (9): يبين المتوسطات والانحرافات المعيارية للبيئات المدرسية المختلفة من خلال مقياس تحديد البيئية المدرسية

\begin{tabular}{|c|c|c|c|c|c|c|}
\hline \multicolumn{6}{|c|}{ البيئة المدرسية } & \multirow{3}{*}{ البيئة المدرسية } \\
\hline \multicolumn{2}{|c|}{ الحكومية } & بية) & اللغاد & & & \\
\hline$\varepsilon$ & P & $\varepsilon$ & p & $\varepsilon$ & م & \\
\hline
\end{tabular}

Doi: $10.12816 / 0034808$ 
مجلة الدراسات التربوية والانسانية ـ كلية التربية ـ جامعة دمنهور. المجلد السابع- العدد( (1)- لسنة 10 بـ

\begin{tabular}{|c|c|c|c|c|c|c|}
\hline r.or & IN.KY & r... & YV.TT & 0.11 & $\varepsilon \vee . \vee \wedge$ & المعلمة \\
\hline r.乏A & 11.01 & r.tr & $10 . \mathrm{V}$. & $\varepsilon . \varepsilon \wedge$ & Mr.ON & 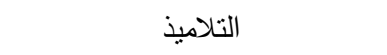 \\
\hline 1.10 & A.r & r.r人 & $1 \wedge .49$ & T.r人 & rv.rq & الأنشطة داخل الفصل \\
\hline 1.04 & A.r人 & $1 . V r$ & 17.29 & r.rq & $r 9.9 \varepsilon$ & الأنشطة التعليمية داخل المدرسة \\
\hline 1.10 & سז.. & $r . \Sigma q$ & IT.VT & $r .17$ & YV.IA & الإشراف الإداري \\
\hline $1.2 \Lambda$ & $V . r \varepsilon$ & $1 . V V$ & 15.70 & $0.7 \mathrm{~V}$ & 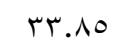 & الإمكانيات المختلفة للبيئة المدرسية \\
\hline r.OV & $71.9 \leqslant$ & r.q. & $97 . .7$ & v. . . & ו人צ.Y & الارجة الكلية \\
\hline
\end{tabular}

جدول (· (1): يبين تحليل التباين (F-test) لأبعاد مقياس البيئة الددرسية على

البيئات المدرسية المختلفة (الأجنبية - اللغات - الحكومية)

\begin{tabular}{|c|c|c|c|c|c|c|}
\hline \multicolumn{6}{|c|}{ البيئة المدرسية } & \multirow{3}{*}{ البيئة المدرسية } \\
\hline \multicolumn{2}{|l|}{ الحكومية } & \multicolumn{2}{|l|}{ اللغات } & \multicolumn{2}{|l|}{ الأجنبية } & \\
\hline مستوى الدلالة & فيمة & مستوى الدلالة & فيمة & مستوى الدلالة & فيمة & \\
\hline 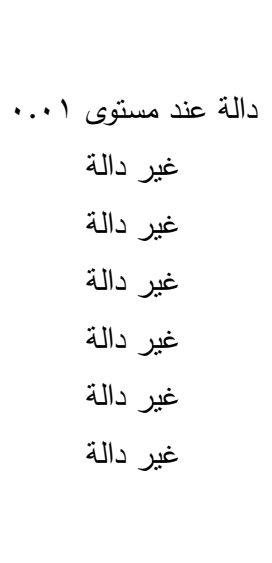 & $\begin{array}{l}r . v 1 \\
. . v 1 \\
r . .0 \\
r . r 1 \\
1.0 r \\
1.17 \\
. .10\end{array}$ & 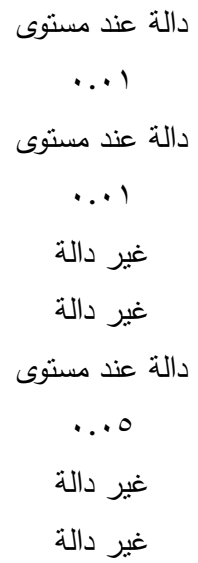 & 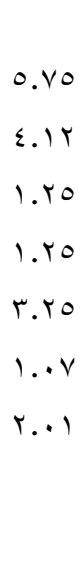 & 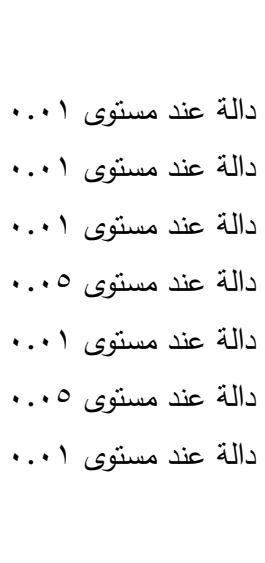 & $\begin{array}{l}0 . V 0 \\
\varepsilon . r T \\
\varepsilon .11 \\
r . V . \\
\varepsilon . r 4 \\
r . V V \\
V .19\end{array}$ & 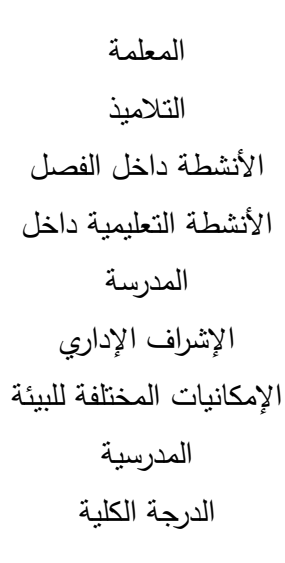 \\
\hline
\end{tabular}

يتضح من نتائج جدول ( • () أن البيئة المدرسية الأجنبية دالة على الأبعاد

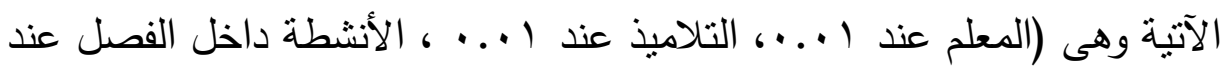

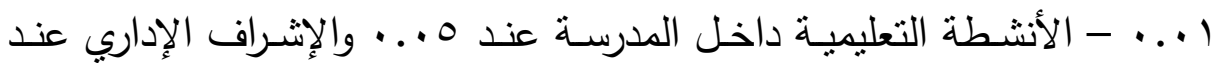

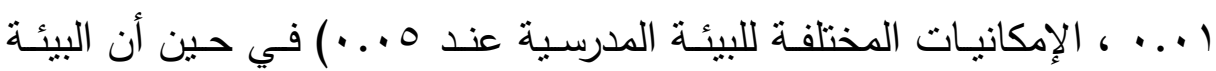

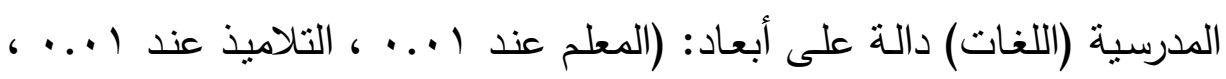

$$
\text { الإشراف الإداري عند ه... (·). }
$$


من خلال نتيجة الجدول (• (1) بأنه بالرغم من اختلاف البيئات المدرسية

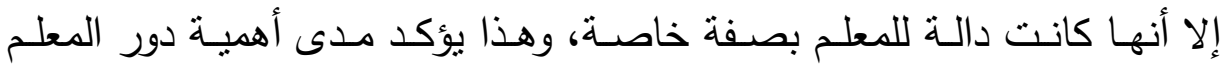
وقدرته وفاعليته في البيئات المدرسية المختلفة مهما اختلفت نوعيتها وتأثيره على دهى دوريه

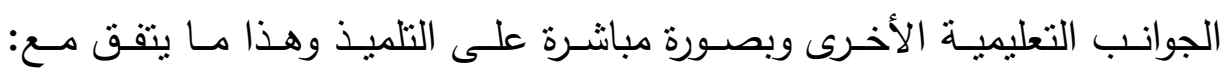
1986 الثرقاوي ه . . ب.أما البيئة المدرسية التي تهتم باحتياجات التلميذ وإنشباعها بما يتفق مع متطلبات نموه وإحساسه بذاته، والتي تتيح علاقة ديمقراطية بين المعلم

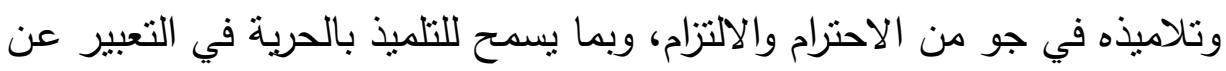

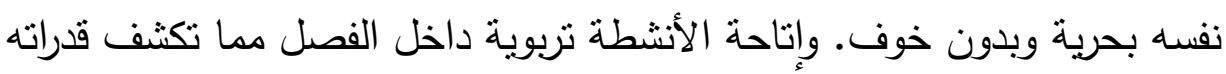

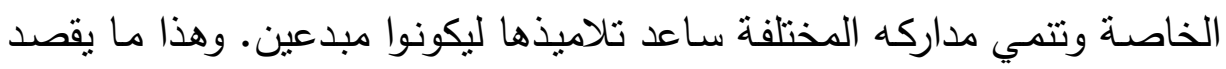

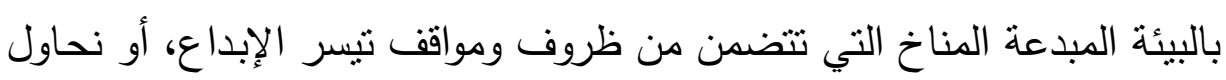
إطلاق طاقات المتعلم الإبداعية، وتقسم هذه الظروف إلى قسمين:

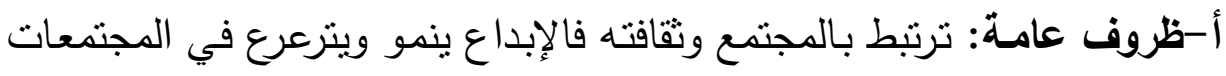

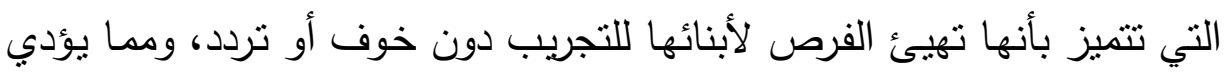
إلى تشجيع على فقد وتطوير الأفكار العلمية والرياضية والأدبية.

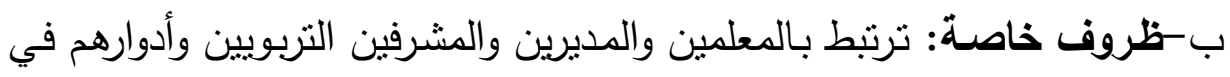
تهيئة الظروف والبيئة المدرسية لتنمينه الإبداع لدى الطلاب. برابـ (http://www.arabsys.net) الابتكار استعداد هناك عوامل تؤدي أن يكون الفرد مبتكراً أو غير مبتكر مثل

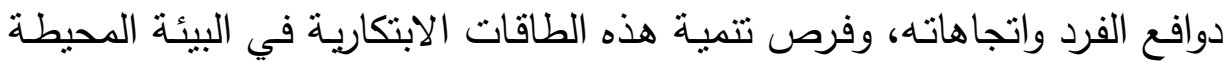

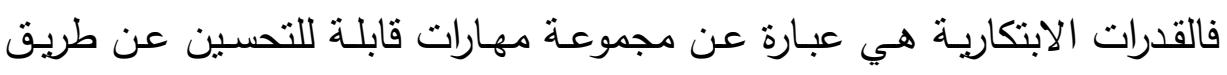

التكوين والتدريب.(يhttp://www.diwanalarab.com) هذا لا يمكن أن يحسن بدون معلم كفؤ قادر على أداء مهامـه التربوية والمهنية

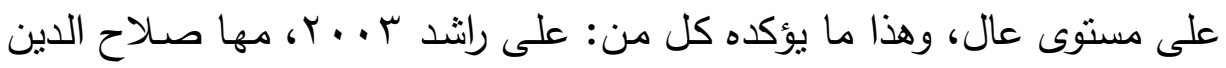

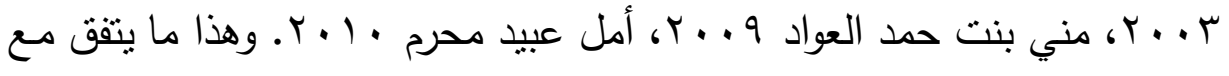
Doi: $10.12816 / 0034808$ 
AMarklag, Ridman 1986 ،Ahern, J 1974

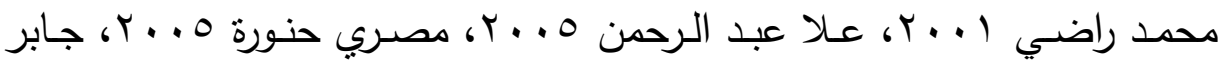

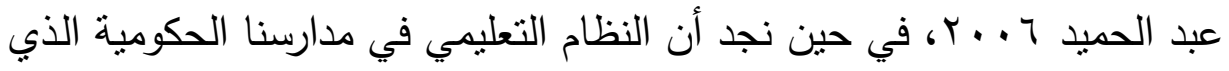
يتسم تتجيع التحصيل الدراسي من خلال الحفظ والتلقين ولا يتيح للطلاب إبراز ذواتهم مما يعيق السلوك الابتكاري الذي هو محصلة عديدة لاكتثـاف قدراتهم

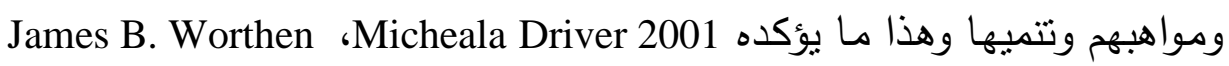

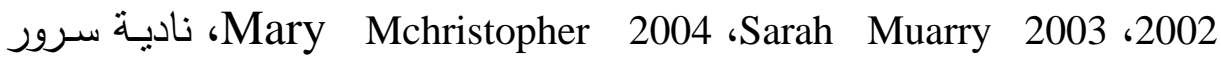

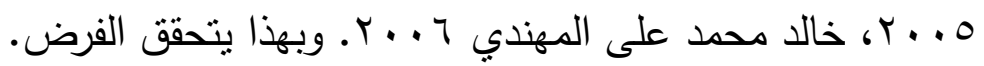
الفرض الثاني: توجد فروق ذات دلالة إحصائية بين البيئات العدرسية ومفهوم الأات لاى التلاميذ.

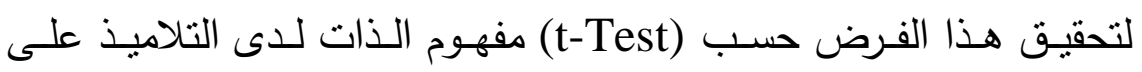
البيئات المدرسية المختلفة (الأجنبية - اللغات - الحكومية) كما في جدول (l)

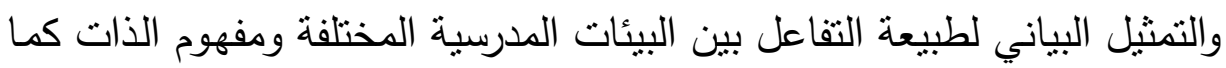

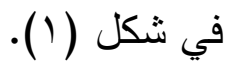

جدول (1 1 ): يبين (1-Test) ودلالتها الإحصائية على مقياس مفهوم الذات على البيئات المدرسية المختلفة.

\begin{tabular}{|c|c|c|c|}
\hline \multicolumn{3}{|c|}{ مفهوم الذات } & \multirow{2}{*}{ البيئة المدرسية } \\
\hline ت ت ودلالتها & $\varepsilon$ & b & \\
\hline ץף 0.7 دالة عند مستوى ا +.. & 15.019 & $10 \mathrm{~V} .01 \mathrm{~V}$ & البيئة المدرسية الأجنبية \\
\hline 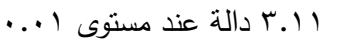 & IV.AVq & ITr.0T7 & البيئة المدرسية (اللغات) \\
\hline 9 "... غير دالة & $1 \cdot . \leqslant \wedge$ & $111 . v \varepsilon$ & البيئة الددرسية(الحكومية) \\
\hline
\end{tabular}

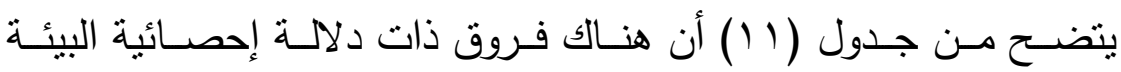

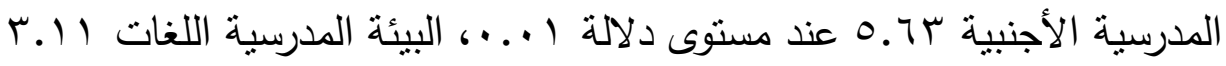
عند مستوى دلالة ا ... في حين البيئة الحكومية ليس لها دلالة. وهذا ما يشير ألن كار Alencar إلى أن النظام التعليمي في كثير من الدول قد يعيق أو يكبت

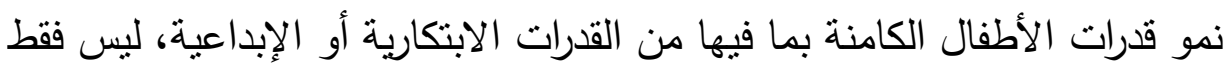
$1 \leqslant r$ 
بسبب تأكيده على الحفظ والاسترجاع وجعل الأطفال حفظه، إنما أيضـا بسبب

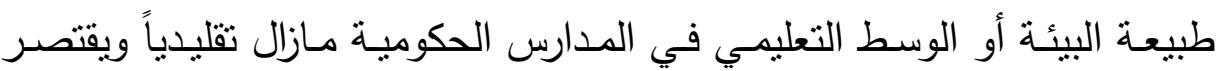
على الحفظ والتلقين يؤدي إلى عدم تتمية شخصياتهم وعدم إحساسهم بذواتهم

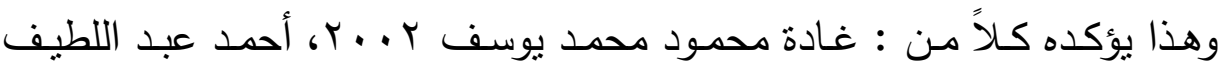

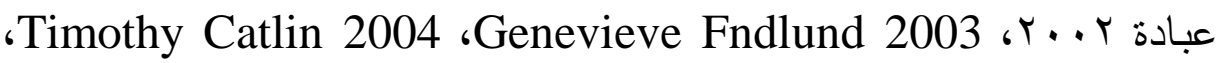

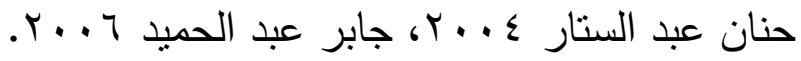
أن الموقف المدرسي الذى يحقق توقعات التلميذ ويقابل احتياجاته سوف يؤدى إلى تحقيق نوافقه، وإلى شعوره بذاته الموقف المدرسي الذى يكرهه التلميذ

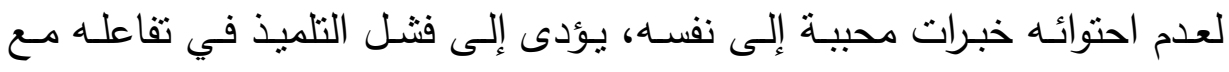

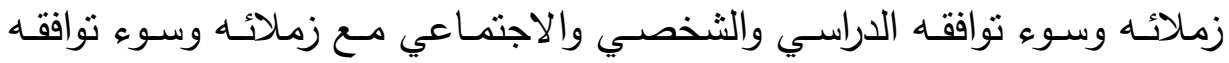

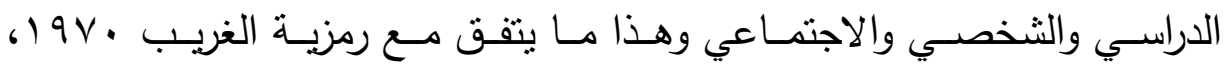

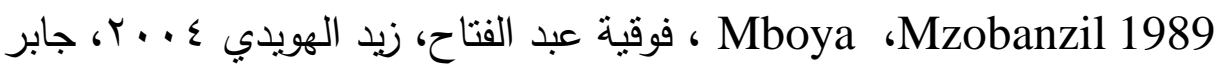

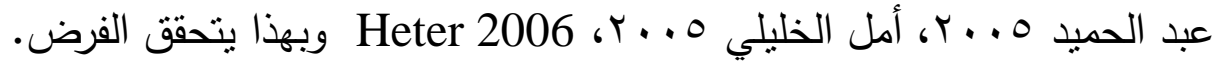
الفرض الثالث: توجد فروق ذات دلالة إحصائية بين البيئات المدرسية المختلفة والابتكارية لدى التلاميذ.

لتحقيق هذا الفرض تم حسـاب المتوسط والانحراف المعباري ( t-Test) لمقيـاس الابتكـار كمـا في جدول (r I ( ) حسب (t-Test) على أبعـاد مقيـاس

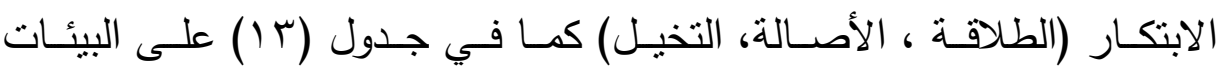

$$
\text { المدرسية المختلفة ( الأجنبية - اللغات - الحكومية) }
$$

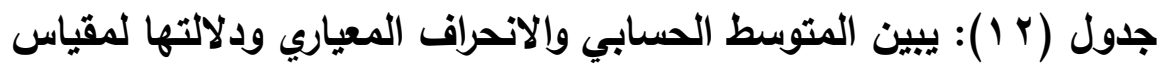
الابتكار على البيئات المدرسية المختلفة (الأجنبية - اللغات - الحكومية)

\begin{tabular}{|c|c|c|c|}
\hline \multicolumn{3}{|c|}{ الابتكار } & \multirow{2}{*}{ لبيئة المدرسية } \\
\hline ت ت ودلالتها & $\varepsilon$ & م & \\
\hline 11 0.1 دالة عند مستوى 1... & A.) $\varepsilon$ & 110.00 & البيئة الأجنيية \\
\hline | 1.1 غير دالة & rY. $\{\varepsilon$ & $07 . .$. & البيئة اللغات \\
\hline r ب... غير دالة & YA. I & $\sum V . T V$ & البيئة الحكومية \\
\hline
\end{tabular}

Doi: $10.12816 / 0034808$ 
يتضـح مـن الجدول (Y I) أن هنـاك فـروق ذات دلالــة إحصـائية للبيئة

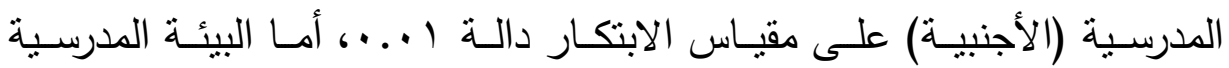
(اللغات - الحكوميـة) غير دالـة وهذا قد برجع إلى اهتمـام المجتمعات الغربيـة بالتعليم باعتباره ضرورة اجتماعية واقتصـادية من خـلال تفجر الطاقات البشرية والقدرات العقلية التي تتيح التقدم الحضاري والرقى الإنساني.

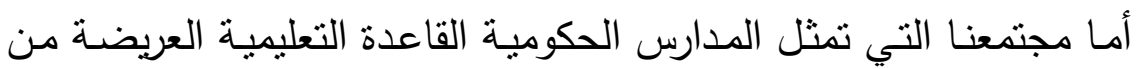

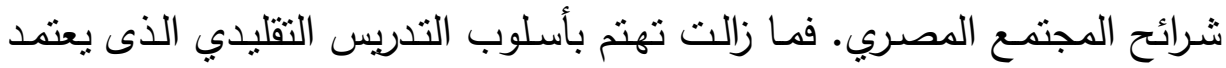
على التلقين والحفظ، يقتصر دورها على مجرد نوصيل المعلومات إلى الطلاب

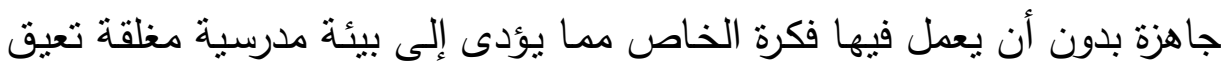

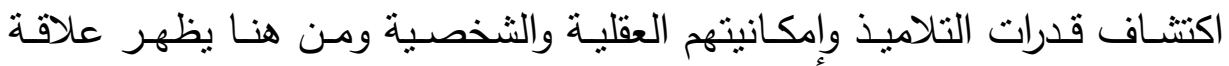

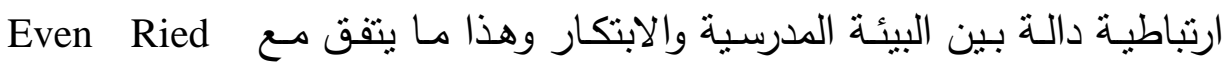
1972، Marlow Ediger2000، Aiexwhitson1994، Lenore Blank 1993

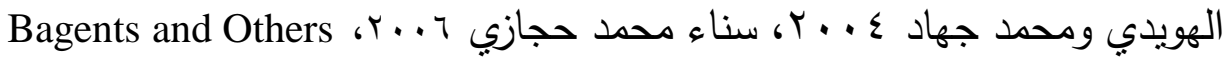
2008.أما في جدول (r ا ( يبين وجود فروق ذات دلالة إحصائية أبعاد الابتكار (الطلاقة، الأصالة، المرونة) من خلال البيئات المدرسية المختلفة فنجد أن للبيئة المدرسية (الأجنبية) ودالة عند مستوى ا +. في حين البيئة المدرسية (اللغاتالحكومية) غير دالة.

جدول (r ( ) يبين المتوسط الحسابي والاتحراف المعياري ودلالتها لمقياس الابتكار على البيئات المدرسية (الأجنبية - اللغات - الحكومية)

\begin{tabular}{|c|c|c|c|c|c|c|c|c|c|}
\hline \multicolumn{9}{|c|}{ مقياس الابتكار } & \multirow{3}{*}{ المدرسية } \\
\hline \multicolumn{3}{|c|}{ التخيل } & \multicolumn{3}{|c|}{ الأصالة } & \multicolumn{3}{|c|}{ الطلاقة } & \\
\hline وديمة ت & $\varepsilon$ & p & قودلاتهة ت & $\varepsilon$ & p & قودلالتها & $\varepsilon$ & p & \\
\hline
\end{tabular}


علاقة كل من التفكير الابتكارى ومفهوم الذات بالبيئة المدرسية بالبيئة المدرسية أ. د. م. سميرة المذكوري

\begin{tabular}{|c|c|c|c|c|c|c|c|c|c|}
\hline ז. . & & EY.T & ت 7 & & & r ـ ـ9 دالة & & $\varepsilon \vee . Y$ & \\
\hline عند دالة & & r & 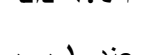 & 1 ... & & عند ا +.. & $1 \cdot .9$ & V & ت. \\
\hline غير دالة & 11 & $1 V .7$ & عند الب. & 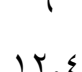 & 191 & 1. 1. غير & $\varepsilon$ & ro.. & الاجببية \\
\hline 1.14 & 01 & 7 & עآ. • غبر & $1 . .0$ & $\mid V .1$ & دالة & 1.74 & • & الحكى مية \\
\hline غير دالة 1 . 1 & 9.7 & $\begin{array}{c}\text { r T.r } \\
r\end{array}$ & دالة & 9.74 & $\varepsilon$ & 9 1 9 .. غير & $\Lambda . \Sigma Y$ & $\begin{array}{c}r \leq .7 \\
r\end{array}$ & \\
\hline
\end{tabular}

وهـذا نتيجـة تعكس حجـم المشـكلة وخطورتهـا بـالتعليم. لمــــــان الأطفـال الموهوبون لا يميلون إلى الحفظ والتلقين، بل ينتجون أساليب في التعلم الاكتثافي

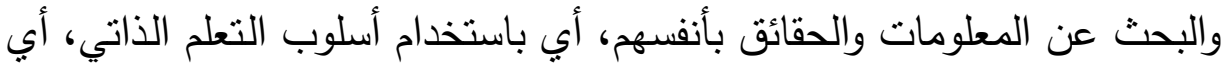

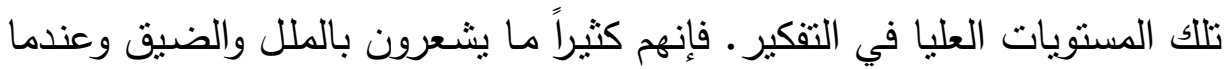
يستخدم المعلمون طرائف تقليدية في التدريس تقوم على أساليب التلقين والتفكير

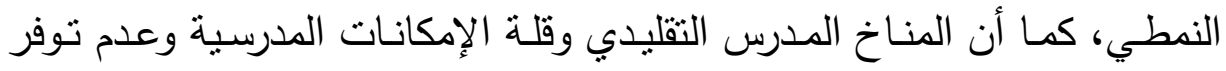

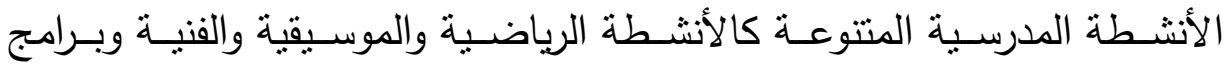
الرحلات والزيـارات، كل ذلك يبعث على السـأم والملل لدى الأطفال والتلاميذ الده (الموهوبين ويعوق نموهم الطبيعي الحر •-http://www.elssafa.com/kids $\underline{12 . \mathrm{htm})}$ لذا يتضـح أهميـة النظـام التعليمسي الذي يثـجع على التلقائيـة والابتكـار

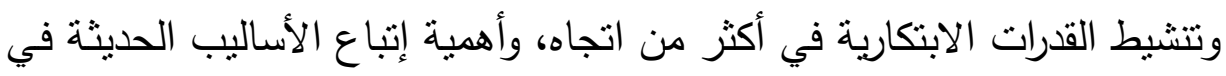

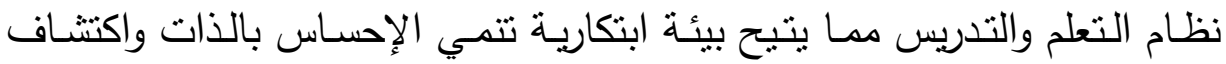
القدرات والتعبير عن إمكانيتها مما يفجر الطاقات الابتكارية للتلاميذ وهذا ما يؤكد Christan Parenting 2002 فايزة يوسف ץ . . T، Loveless 2013 وبهذا يتحقق

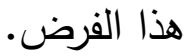
الفرض الرابع: يختلف مفهوم الذات لدى الجنسين باختلاف البيئات المدرسية

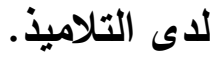


لتحقيـق هذا الفرض حسبت المتوسطات الحسـابية والانحرافات المعياريـة قيمـة (T-test) ودلالتها الإحصـائية لمفهوم الذات من خـال البيئات المدرسية

$$
\text { المختلفة (الأجنبية - اللغات - الحكومية). }
$$

جدول ( 1 ) ): يبين (t-Test) ودلالتها الإحصائية لمقياس مفهوم الذات على ) البيئات المدرسية المختلفة لاى الجنسين.

\begin{tabular}{|c|c|c|c|c|c|}
\hline \multirow{2}{*}{ ت ت ودلالتها } & \multicolumn{4}{|c|}{ مفهوم الذات } & \multirow{2}{*}{ البيئة المدرسية } \\
\hline & $\varepsilon$ & b & $\varepsilon$ & s & \\
\hline \multirow{5}{*}{ 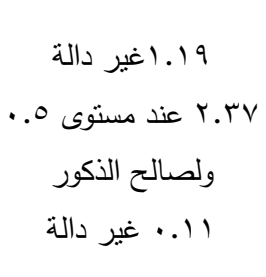 } & r). $\leqslant \wedge$ & $\leq 7.7 \wedge$ & Tr.0T & $T \vee . \Sigma T$ & البيئة المدرسية الأجنبية \\
\hline & $\mid 1.41$ & $1 \varepsilon \ldots$ & 11.1. & r纟.r. & البيئة المدرسية(اللغات) \\
\hline & & & & & \\
\hline & & & & & \\
\hline & $1 . . \wedge V$ & iv.ro & N.or & 17.94 & البيئة المدرسية (الحكومية) \\
\hline
\end{tabular}

يتضـح من الجدول (ع () أنـه لا يوجد فروق ذات دلالمة إحصـائية للبيئة

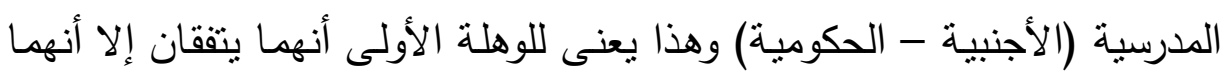

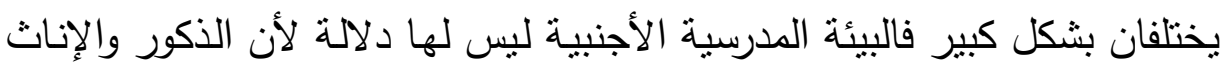

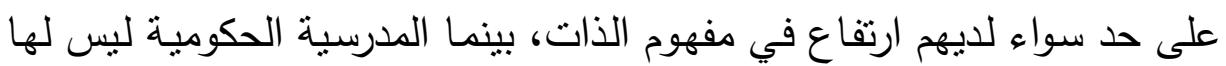
دلالة (للذكور والإناث على حد سواء) أي لديهم انخفاض في مفهوم الذات. شكل ( 1): يبين التمثيل البياني طبيعة التفاعل بين البيئات المدرسية المختلفة مقياس مفهوم الأات

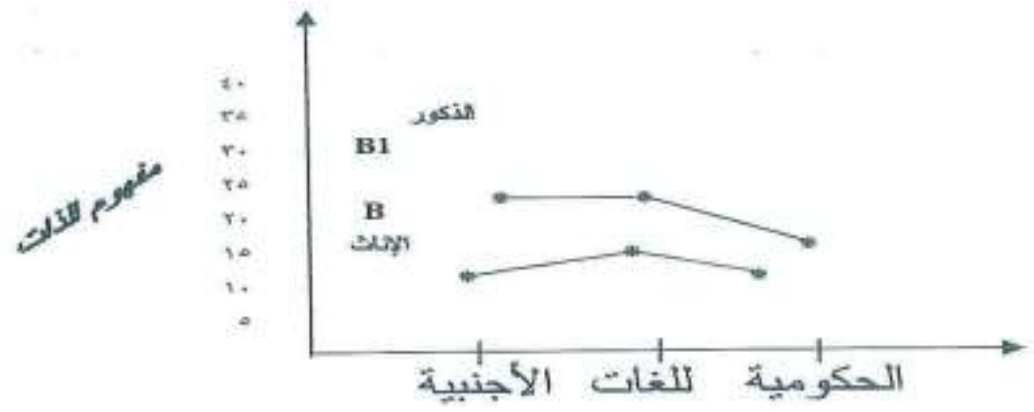

يتضـح مـن الثـكل ( ) أن الخطين B-B1 يبتعـدان بشكل واضـح عـن التوازي وهذان الخطان يمثلان المتوسطات الحسابية للرجات أفراد على البيئات 
المدرسية المختلفة (الأجنبيـة - اللغـات - الحكوميـة على مفهوم الذات. كذللك

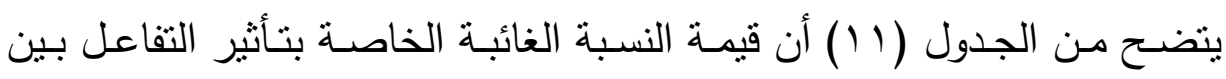

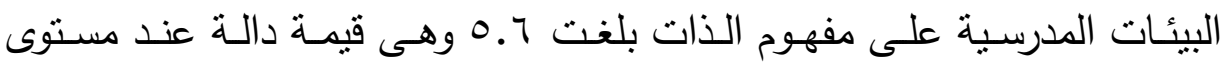
1. .. وهذا يعني أن هناك تأثير وإلا للتفاعل بين متغيري البيئة المدرسية ومفهوم

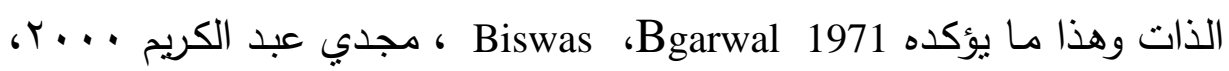

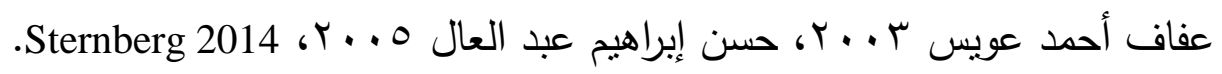

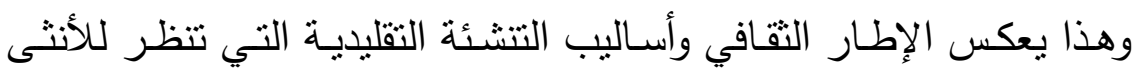
بالتعبية دون إتاحة فرص الاستقلالية للقدرة على اتخاذ القرار والتعبير عنى نفسها لإسها

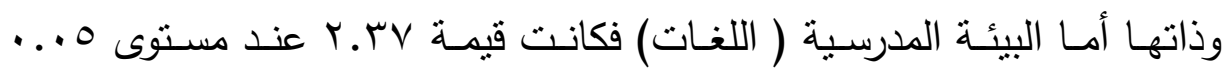
لصالح الذكور أي أن الذكور يجدو قدراً من الإحساس بذواتهم عن الإناث وهذا لهات

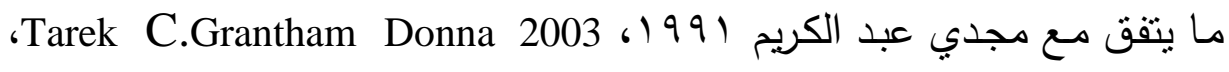
Elliot 1980, Ursula Althenstaelt في حين اختلف مع 2004 ،Parricia 2004 Thalma

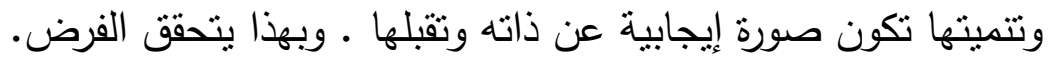
الفرض الخـامس: يختلـف مفهـوم الابتكـار لــى الجنسـين بـاختلاف البيئـات المدرسية المختلفة لاى التلاميذ.

t-) لتحقيق هذا الفرض حسبت المتوسط الحسـابي والانحراف المعيـاري

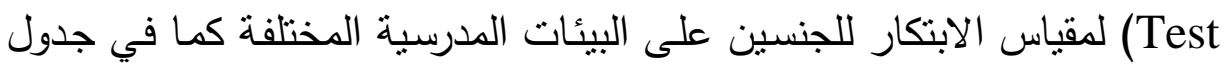
(0) والتمثيل البياني لطبية التفاعل بين البيئات المدرسية ومقياس الابتكار كما

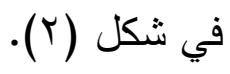




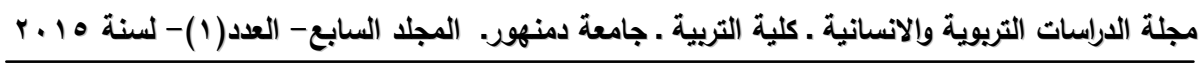

جدول (0 1 ): يبين (t-Test) لمقياس الابتكار على البيئات المدرسية المختلفة

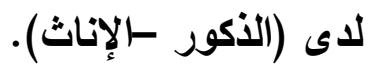

\begin{tabular}{|c|c|c|c|c|c|}
\hline \multirow{2}{*}{ ت ت ودلالتها } & \multicolumn{4}{|c|}{ الابتكارية } & \multirow{2}{*}{ البيئة المدرسية } \\
\hline & $\varepsilon$ & p & $\varepsilon$ & p & \\
\hline 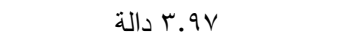 & $r \cdot . \varepsilon \varepsilon$ & $15 \cdot .9$ & $r \cdot . \varepsilon \varepsilon$ & $1 \cdot r . .7$ & البيئة المدرسية الأجنبية \\
\hline عند مستوى ا ... ولصالح الإناث & & $r$ & & & \\
\hline r ـ ـ ـ غير دالة & $r \cdot r_{0}$ & & $1 \wedge . r \Lambda$ & $T \Sigma . V T$ & البيئة المدرسية(اللغات) \\
\hline 1 1 ـ ا غير دالة & 18.91 & 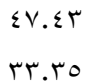 & $\mid 7.41$ & $\varepsilon r . \leqslant V$ & البيئة المدرسية( الحكومية) \\
\hline
\end{tabular}

يتضح من جدول (0 1) أنه لا توجد فروق ذات دلالة إحصائية لدى البيئة

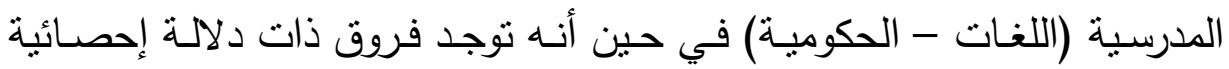
للبيئة المدرسية الأجنبية عند مستوى ا ... لصـالح الإنـاث وهذا نتيجـة مثيـرة للجدل ولكن قد تفسر عن طبيعة الإمكانيات المدرسية المتاحة والأنشطة المدرسية المختلفة التي تتيح لظهور ابتكارات إناث من خلاص الأنشطة الفنية (التطريز النحت - الرسم - التلوين - الخزف) والطهى بالإضـافة إلى أنشطة موسيقية (عزف جماعي- غناء- عزف فردي) الأنشطة المسرحية (تأليف - كتابة حوار وسيناريو - إخراج- تصوير - تمثيل) بالإضافة على أنشطة صحفية من خلال إصدار جريدة شهرية والعديد من الأنشطة المختلفة في التربية الرياضية (كرة سلة - قدم - تسـلق .....إلـخ) بالإضـافة إلى الجـو المدرسـي الذى يتسـم بالحريـة

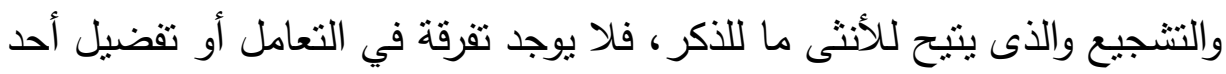

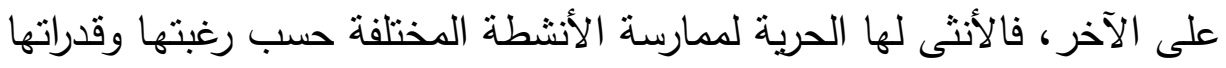
والنبوغ فيها وهذا مما أدى إلى ارتفاع الابتكار لدى الإنات عن الذكور ـ التفكير

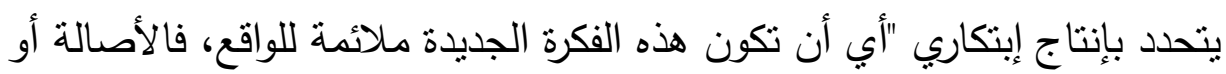

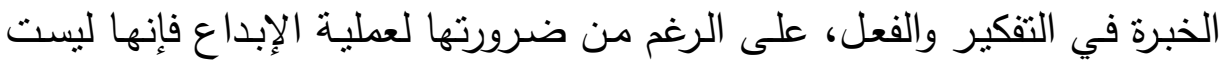

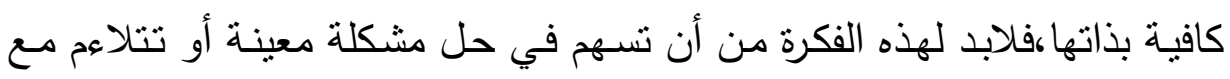
موقف معين أو حقق هدفاً بذاته وليس هناك علاقة بينها وبين نوع الجنس ذكور

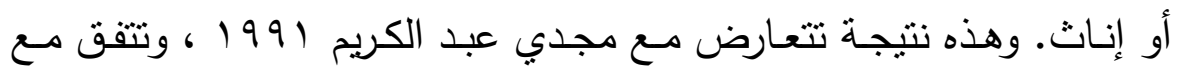


Gerlach ،Li-Fangzhan 2004 ،Flack Jerry 2001 ،Meador Karen 2001

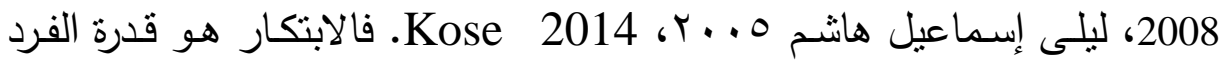

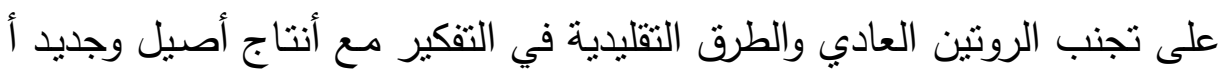
غير شائع يمكن تتفيذه أو تحقيقه، أو هو إنتاج جديد مقبول ونافع يحقق رضاء

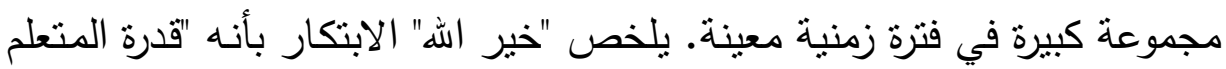

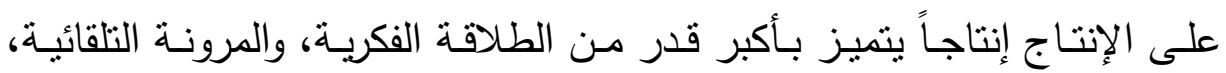
والأصالة وبالتداعيات البعيدة وذلك كاستجابة لمشكلة أو موقف مثير . (http://www.arabsys.net)

فالطفل المبتكر هو صـاحب المفاجـآت في التعبير فتلاحظـه مـن خـلال

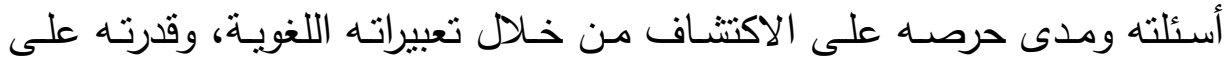

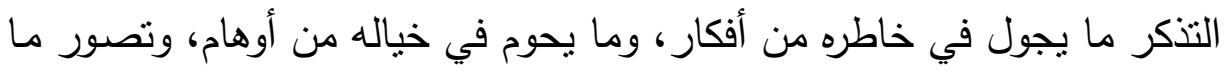

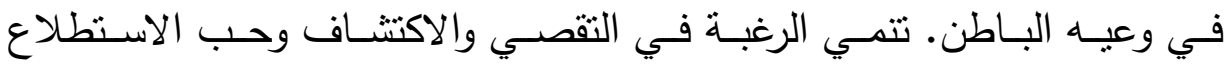

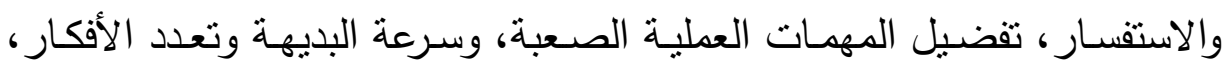
ومرونة التفكير والتقة بالنفس، والقدرة على التخيل والتركيب وتتكيل للوصول إلى

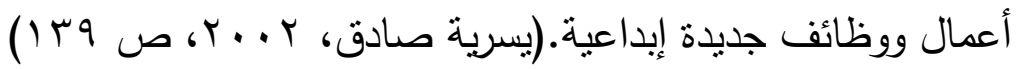
شكل (ץ): يبين التمثيل البياني لطبيعة التفاعل بين البيئات المدرسية المختلفة

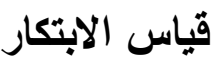

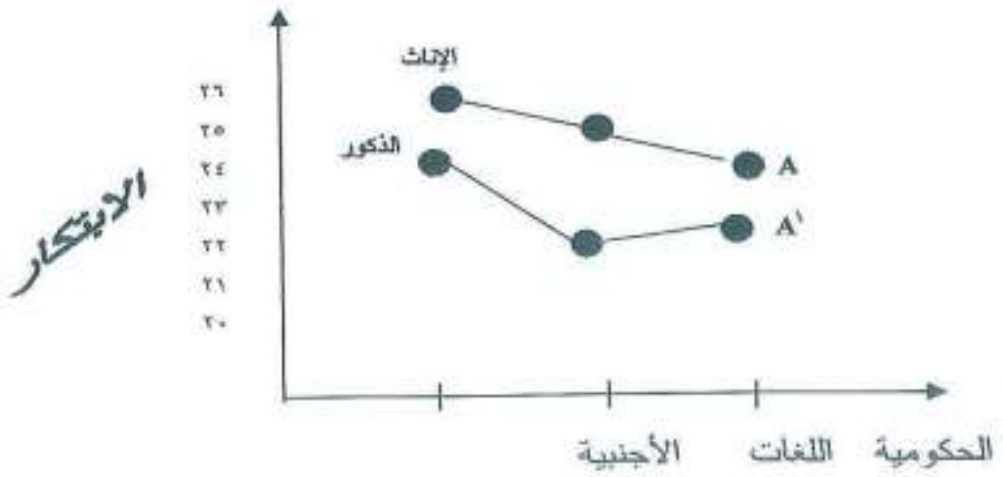


يتضـح مـن الثـكل السـابق الخطين غيـر متوازيين وهـذا يمـثلان المتوسطات الحسابية لدرجات أفراد العينة ويرى Dan Simon 2004 في تفسير مثل هذه الأثكال أن تأثنر التفاعل يعتبر غير موجود في توازي الخطين تماماً.

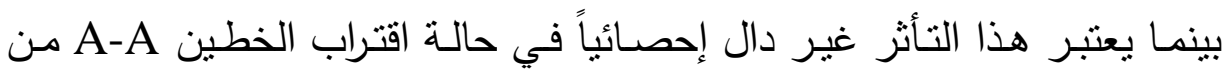

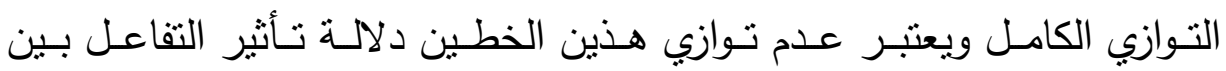

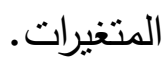

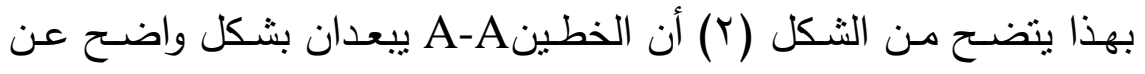

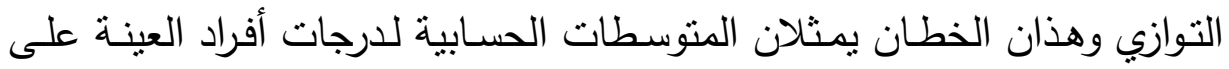
البيئات المدرسية المختلفة ومن الثكل يتضح تأثنير الابتكار على تباين البيئات

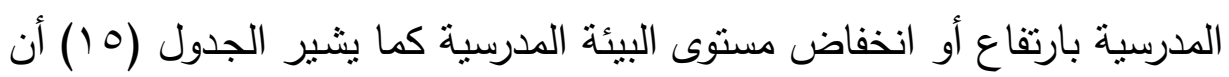

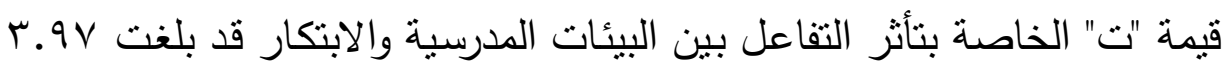
وهـى قيمـة دالـة عند مستوى ا ... وبالتالي بمكن القول أن هنـاك تأنثيرا دالاً

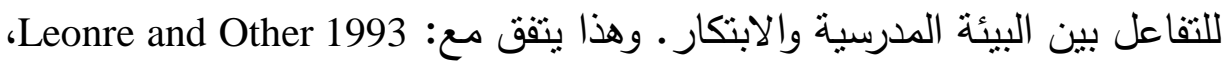

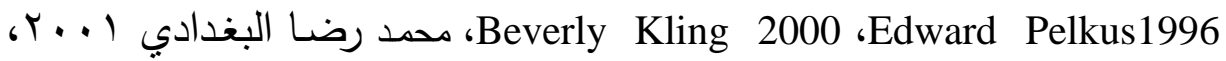

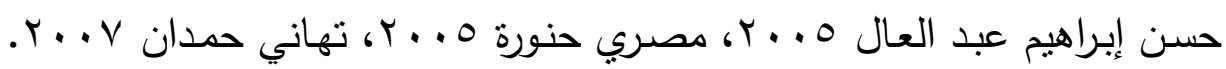
بهذا يتحقق الفرض.

الفرض السـادس: يختلف مفهوم الذات والابتكار بـاختلاف البيئات المدرسية المختلفة لاى التلاميذ.

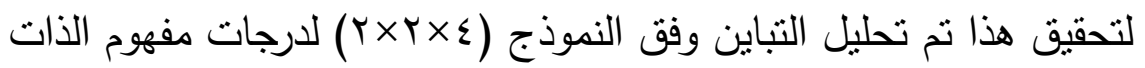
والابتكار من خلال البيئات المدرسية المختلفة (الأجنبية - اللغات - الحكومية) كم في جدول (7 (1) التمثيل البياني لطبية التفاعل بين مفهوم الذات والابتكار على البيئات المدرسية كما في شكل (r). 
علاقة كل من التفكير الابتكارى ومفهوم الذات بالبيئة المدرسية بالبيئة المدرسية أ. د. م. سميرة المذكوري

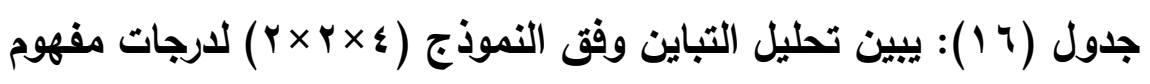

الأات والابتكار من خلال البيئات المدرسية المختلفة

\begin{tabular}{|c|c|c|c|c|}
\hline قيمة ف ودلالتها & متوسط المربعات & درجات الحرية & مجموع المربعات & مصادر التباين \\
\hline 1.07 دالة عند مستوى ا ... & IVT.IV & r & צח. & البيئات المدرسية أ \\
\hline r.Y. دالة عند مستوى | ... & $V 4 . . \varepsilon$ & 1 & V५. & الابتكار ب \\
\hline r Yr. دالة عند مستوى ه ... & 110.1 & 1 & $110 . .1$ & مفهوم الذات ج \\
\hline ه. .ـ دالة عند مستوى 1 ... & 09.7 & $r$ & Yos.r & ألاب \\
\hline 1الة 0.7 دالة مستوى | ... & or.r & $r$ & $194 . \varepsilon$ & أبج \\
\hline ז.7 دالة عند مستوى | ... & ฯ... & 1 & 14.1 & 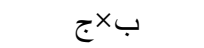 \\
\hline \multirow[t]{3}{*}{ ᄉ. 1} & $\leqslant \vee .0$ & $r$ & r70.r & 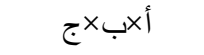 \\
\hline & Tr.tr & $\leqslant 11$ & 9101.7 & 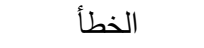 \\
\hline & & $\leqslant\rceil \leqslant$ & $1001 \pi . V$ & المجموع الكلي \\
\hline
\end{tabular}

شكل (r): يبين التمثيل البياني لطبيعة التفاعل بين البيئات المدرسية والابتكار ومفهوم الذات

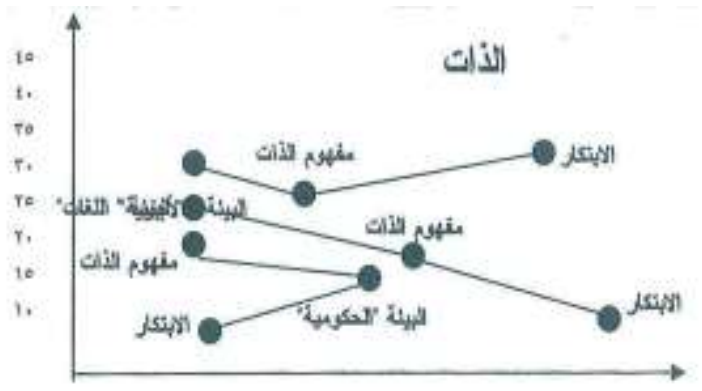

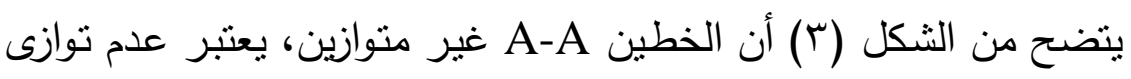
الخطين دلالة تأثير التفاعل بين البيئة المدرسية وكلاً من الابتكار ومفهوم الذات

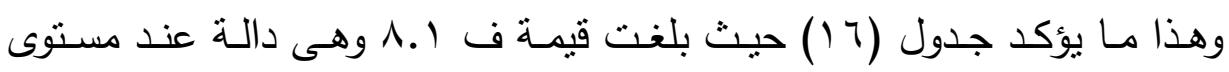

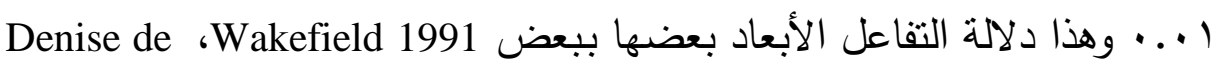
.Smolensky 2015 ،Bagents 2008، Souze

$$
\text { يتضح من الجدول (7 أ) أن: }
$$

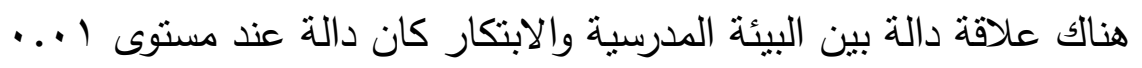

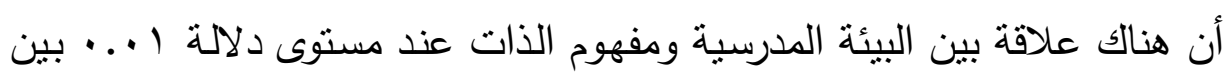
Doi: $10.12816 / 0034808$ 
هناك علاقة البيئة المدرسبة وكلاً من مفهوم الذات والابتكار عند المستوى دالة

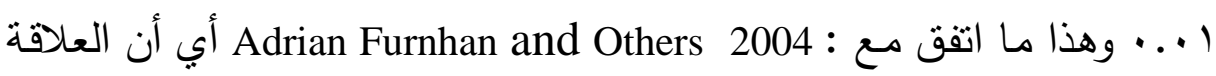
بين البيئة المدرسية والابتكار دالة عند مستوى ال... وذللك لاهتمامها بالطفل

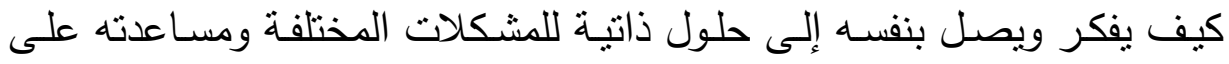
تتمية قدراته الابتكارية وهذا ما يتفق مع دراسات كلاً من: Drager and others

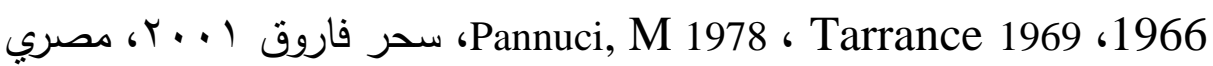

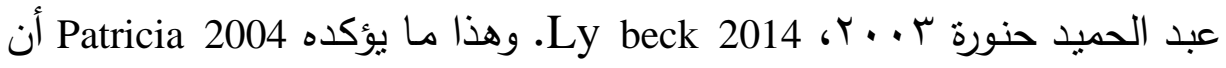
مفهوم الابتكار كعملية عقلية معرفية يحدث داخل العقل من تجهيز للمعلومات وإيجـاد العلاقـات بـين العناصـر والمكونـات المعرفيـة، واسـتخدام الاسـتراتيجيات الملائمة التي ينتج عن التفاعل بينها وبينها محتوى البينة المعرفية ناتجاً ابتكارياً.

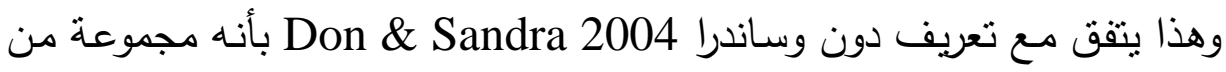
العمليات المعرفية التي تستخدم لتوليد حلول مفيدة وأصيلة لمشكلة. ويخلق مناخ دهاخ اجتماعي تعليمي يشجع على إثارة القدرة الإبداعية أما مباشرة أو غير مباشرة عن لن

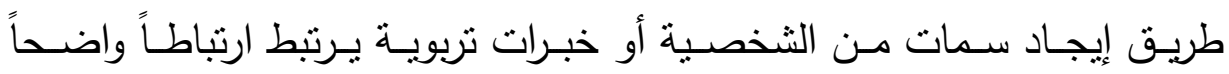
بالإيداع.

أي أن البيئة التعليميـة إذا أحسن المدرس استخدامها وتحديد الهدف منها وتوضيحه في ذهن الطالب سوف تؤدي إلى زيادة مشاركة التلميذ الإيجابية في

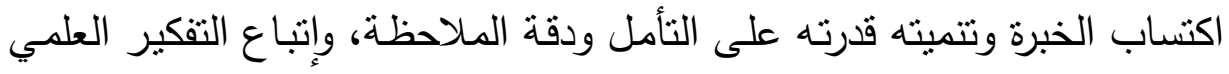
للوصول على حل المشكلات، ويؤدي هذا الأسلوب إلى تحسين نوعية التعليم ورفع مستوى الأداء عند التلميذ. (بhttp://www.atmdares.net/salim) -توجد علاقة بين البيئة الدرسية ومفهوم الذات دالة عند مستوى ا ب... وهذا ما يؤكده كل

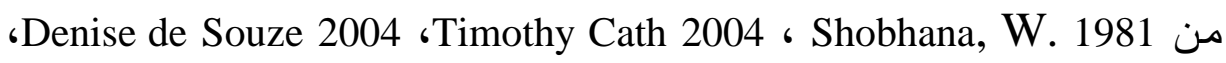
إيمان عبد الله البراوي 9 . . . r. kose 2014 . 
علاقة كل من التفكير الابتكارى ومفهوم الذات بالبيئة المدرسية بالبيئة المدرسية أ. د. م. سميرة المذكوري

-توجد علاقة بين الابتكار ومفهوم الذات دالة عند مستوى ا ... وهذا ما يتفق

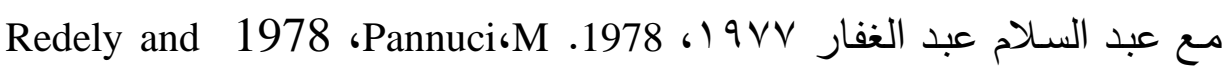

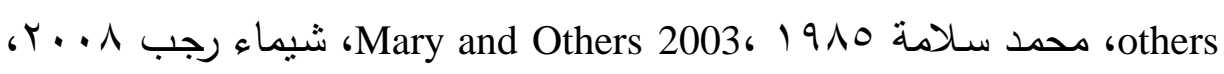

.Loveless 2013

-توجد علاقة بين مفهوم البيئة المدرسية ومفهوم الذات والابتكار عند مستوى

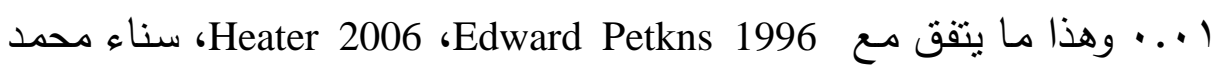

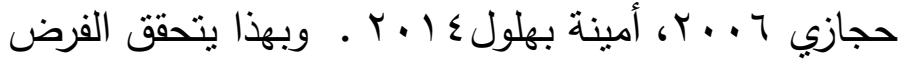




\section{قائمة|تمراجح}

أولاً: المرحع العربية:

1-أحمد عزت راجح ( • ( ) ): "أصول علم النفس"، الطبعة السابعة، دار النهضة العربية،

القاهرة.

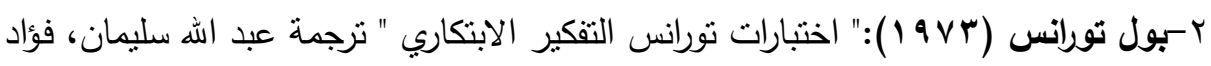
أبو حطب، مقدمة نظرية، الأنجلو المصرية، القاهرة.

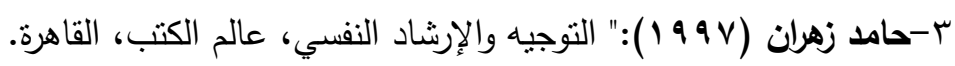

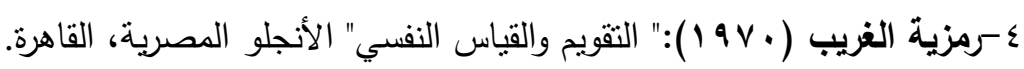

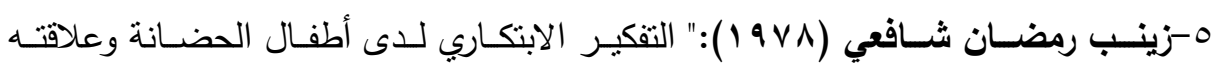

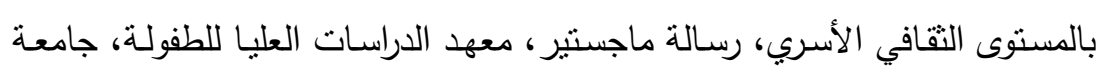

$$
\text { عين شمس. }
$$

4سالم محمد سالم ( ـ 99 1): "بعض السمات المزاجية للتلاميذ في أنواع مختلفة من البيئة

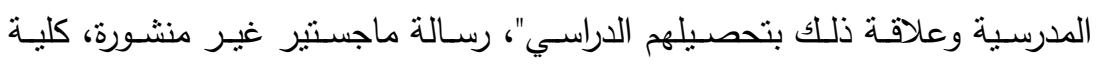
التربية، جامعة المنوفية.

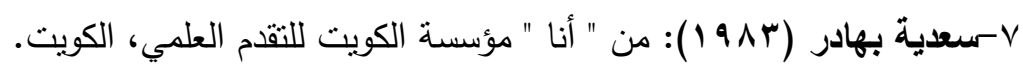

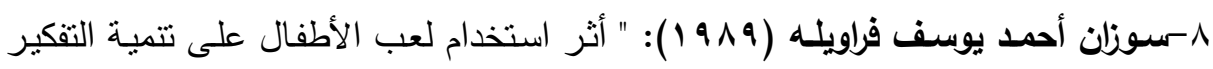
الابتكاري لاى طفل الحضانة " رسالة ماجستير ، كلية التربية، جامعة الإسكندرية.

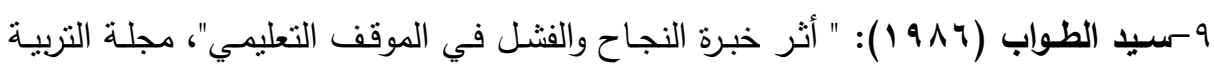

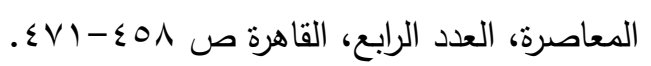

• ( اسيد صبحي (19V7) ):" بحوث ودراسات في الابتكار ، عالم الكتب، القاهرة.

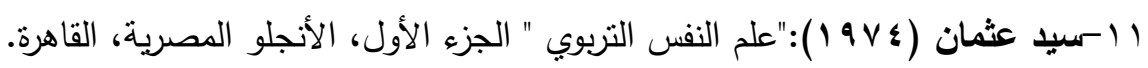

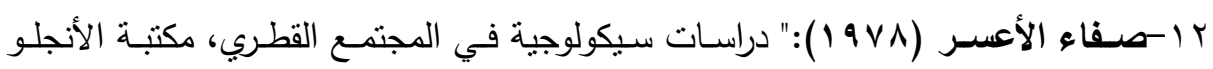

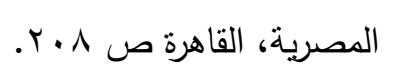

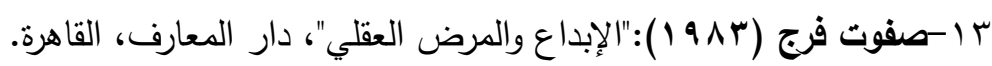

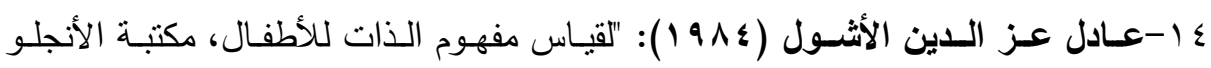
المصرية، القاهرة.

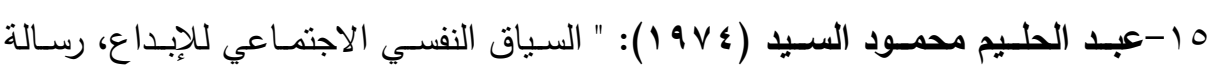
دكتوراه، غير منشورة، كلية الآداب، جامعة القاهرة. 


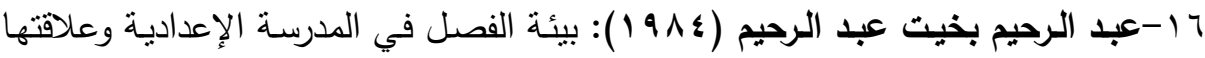

$$
\text { بالإنجاز الأكاديمي، المنيا، دار حراء. }
$$

IV

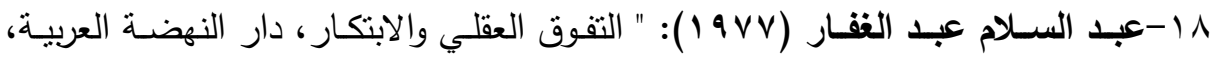
القاهرة.

9 1 -عبد الهادي السيد عبده (919 1 )): " البيئة المدرسية والذكاء وعلاقتهما بالحكم الخلقي لدى أطفال الحلقة الأولى للتعليم الأساسي"، مجلة التربية - جامعة المنوفية، العدد

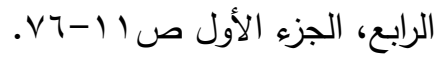

• ץ-على محمود شعيب (9^^1 )): " دراسة ميدانية لسلوك المجازفة من حيث علاقته بمفهوم الذات وسمات الثخصية والتحصيل الدراسي لدى المراهقين مـن طسلاب وطالبـات المرحلة الثانوية بمكة المكرمة "، مجلة كلية التربية، جامعة عين شمس، العدد الثاني

$$
\text { عشر، ص (1V7 (1) (1) ). }
$$

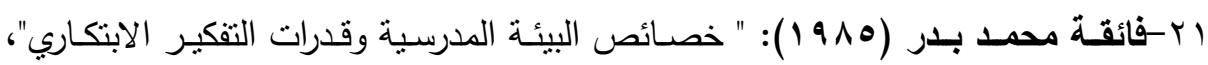
رسالة دكتوراه، كلية التربية، الأنجلو المصرية.

Y Y-مجـدي عبـد الكـريم حبيـب (1991 )): " تفاعليـة عامليـه لمفهوم الذات وتقدير الذات والتفكير الابتكاري لدى عينة من الأطفال الصفين الخامس والرابع والسابع الأساسي

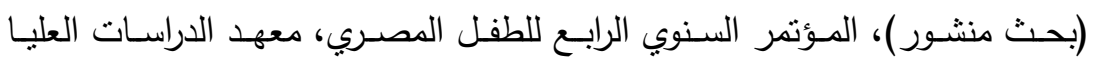
للطفولـة، المؤتمر السـوي الرابع للطفل المصـري، معهد الدراسـات العليـا للطفولـة، المجلد الأول، جامعة عين شمس. ب ب-محمـد الخالـد الطــان (9VVV) ) " دراسـة التفوق العقلي من حيث علاقته باتجاهـات

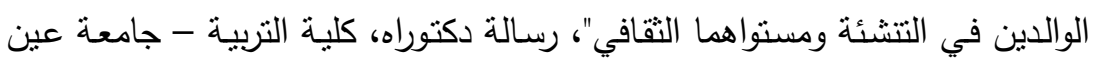
شمس.

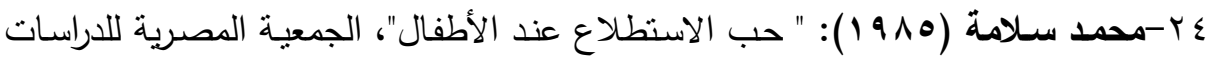
النفسية، المؤتمر الأول لعلم النفس، مكتبة الأنجلو، القاهرة.

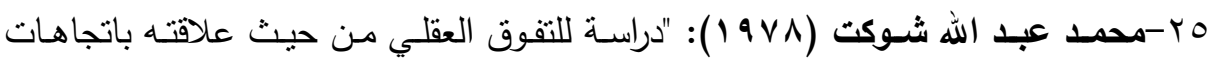
الوالدين في التشئية ومستواهما التقافي". رسالة ماجستير ، كلية التربية، جامعة عين شمس. 


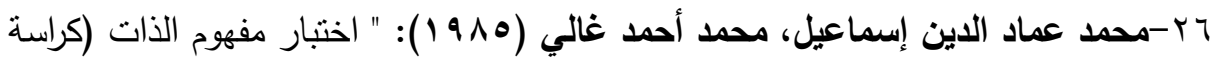
التعليمات)، مكتبة النهضة المصرية، القاهرة.

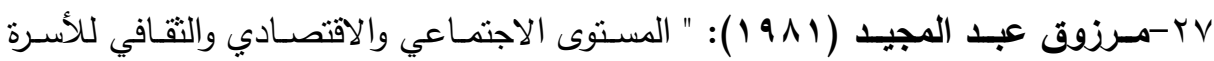

وعلاقته بـالتفكير الابتكاري للأبناء في المرحلـة الابتدائية بـالريف والحضر "، رسالة

ماجستير ، كلية التربية، جامعة الإسكندرية.

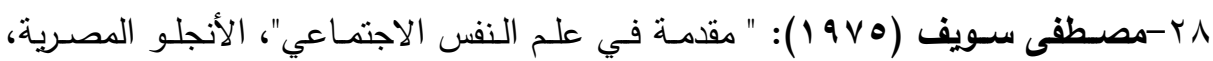

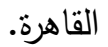

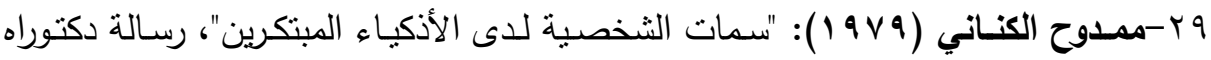

غير منشورة، كلية التربية، جامعة المنصورة.

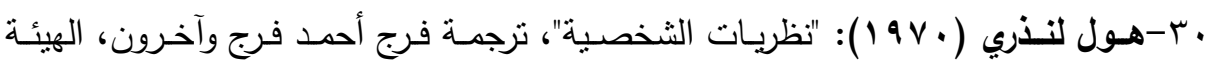
العامة للنأليف والنشر ص

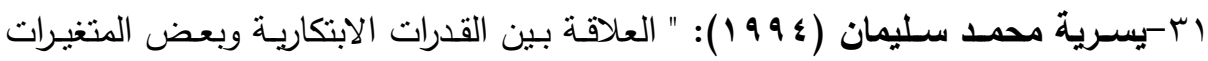

النفسية والاجتماعية لطفل المدرسة الابتدائية"، معهد الدراسات العليا للطفولة، دكتوراه

غير منشورة، جامعة عين شمس.

ثنانياً: المراجع الأحنبية:

32- Agenw, E.M.(1982): "The relationships between Elementary school climate and student achievement". Diss. Abst. Inter. Vol. 43, PP. 360 (A).

33- Ahern, T.J. (1974): "A study of the relationships between local. Cosmopolitan characteristics of teachers. Teacher pupil interaction and student creativity". Diss, Abst. Inter, Vol 35, No. 6.

34- Alex Whitson (1994): "The creative minority in our schools" childhood Education, Vol. 71, No. 1, PP. 2.

35- Barry, G.C (1974): "Teacher Open Closed mindedness as predicts of student creativity progress. Diss. Abst. Inter. Vol. 34, No. 12. PP. 1730 (A).

36- Bates, G.C. (1975): "predicting Learning Environments from teacher and student personality", Diss. Abst. Inter. Vol. 35, PP. (5216-5217).

37- Benton Kathleen (2012): Portrait of inffective educational community. Acase studying school, DAL. A60/69. No.3, PP.314. 
38- Beverly kling (2000): "Assert yourself. Helping students of All Ages develop Self-Advocacy Skills, Teaching Exceptional Children . Vol. 32, N.3, Jan-Feb. PP. (66-70).

39- Biswas, A- and Aggarwal (1971): " Dictionary and Directory of Education" New Dethi: Karol - Baph.

40- Borsbach, Anthany Tobin, Kenneth (1995): "Toward a Critical Approach to the study of Learning Environments in Science classrooms". Research in science education, Vol. 25, N.1, PP.19-32.

41- Brokover W. Bastterson and Thomas (1964): "Self concept of ability and School Achievement Socios of education Vol. 37, PP. 271 - 278.

42- Buranajot, T.A (1972): "A study of the relationship between the verbal interaction of elementary science teachers with their student and students crealivity.

43- Christian parenting (2002): "Raise a Creative thinking" Jan-Feb, Vol. 13, PP.16 (1).

44- Dan Simon and others (2004): " The redux of cognitive consistency theories Evidence Judgments by constraint satisfaction". Journal of personality and social Psychology Vol 86, No. 6. Jun. PP. 814 - 829.

45- David Herbert, (2000): " School choice in the local environment Headteachers as Gatekeepers of an Uneven Playing Field", Journal articles, Vol. 20, No. I, Feb PP. 9- 97.

46- Denise de Souze Fleith (2004): " Effect of a creativity Training program on creative abilities and Self-concept in monolingual and building elementary classroom", Report Review, vol. 26, PP.112 (1).

47- Denny, A.D. Rusch, R. (1974): "Classroom Creativity", observation Schedule (cos) in antia Simon, E. Gilboyer 2 Mirvors for Behavior III, An anthology of observation In struments communication Materials center, Pennsylvania PP, 220 - 222.

48- Drayer, A-S and wells (1966): "Parental values Parental control and creativity in young children", J. of Marriage and Family, Vol. 28. N. 1.

49- Edward petkus (1996): "The creative Identity creative Behavior from the symbolic interactionist perspective, Journal of creative Behavior". Vol. 30, No. 3, PP. 188-196.

50- Elliot, Gregory (1988): "Human sex differences in Self concept and sell. Estem for children childhood and Adolescenc, Brown,

Doi: $10.12816 / 0034808$ 
providence", R. O, Journal of youth and addescence. Feb, Vol. 17(1), PP. (41 - 57).

51- Evon Ried (1972): "An exploratly study of the relationship between selected environment variables and measure of creativity children", diss. Abst. inter. Vol. 32, No. 7.

52- Fames, W., W (1980): "Principle of Psychology". Holt, Vol. 2, NewYork.

53- Forman, Susan (1981): "Effects of Socioeconomic Status on creativity in elementary School Children". Diss. Abst. Inter. Vol. 65, No. 4.

54- Fraser, B. and relout, A., (1980): ": person environment fit in open class room", journal of educational research, vol. 73, PP. 159 - 167.

55- Genevieve Fndlund Margaret Schneider (2003): "Physical Selfconcept in Aaolescent girls. " Behavioral and Physiological correlates ", Research Quarterly for Exercise and sport, Sept Vol. 74, PP. 360 (6).

56- Hall, J.A. (1965): "Study of Relationship between Selected Factores of Orano Organizational climate and Pupils Achievement in Reading Arithmetic and Language". Diss. University of Alabama. No.1 26, 5817A.

57- Halpin, A., and croft, d., (1963): "The organization climate Schools" Chicago university of Chicago.

58- Harris, W.D., (1987): "Effects of an open space environment versus traditional environment on the achievement of high school students". Diss. Abst. Inter. Vol. 84. PP. 356 (A).

59- Huang, Shwu-yong L, Fraser, Barry J. (2014): Science Teachers Perceptions of the school Environment Gender Differences, Journal of Research in Science Teaching, V46, No.4,PP.(404420)

60- Huang, Shwu-yong L., Waxman, Hersh C. (2.15): "The Association of School Environment to Student Teachers satisfaction and Teaching Commitment, Teaching and Teacher Education. An international Journal of Research and Studies, Jol 25, No.2, PP (235-243).

61- James B. Worthen Richard and others (2002): proximity attitude toward objects and people reference to a category and selfrepresentation. The American journal of Psychology, vol. 115, No. 2, PP. 233.

62- Janet Weaver (1972): "Structure and creativity is Sarly childhood Education" Diss Abst. Int vo. 32, No. 8. PP. 4497 (A). 
63- Kose, Erdogen (2014): Assessment of the Effectiveness of the Educational Environment Supported by computer Aided presentations at Primary School Level, Computers \& Education, V.53, No.4, PP.1355-1362.

64- Lenore Blank, Kelner (1993): "The creative classroom" A Book U.S, New Hanpsnire.

65- Li-Fang Zhang (2004): "Thinking Styles university students preferred Teaching style and their conceptions of Effective Teachers". The journal of Psychology No. 138 (3). PP. 233252. May.

66- Loveless, A.L. (2013): Literature Review in creativity, New Technologies and Learning. Brighton Nesta. Www.Neslafuturelab.Org/Research/Reviews

67- Lybeck, g (2014) The Development of Aselv-Renewing School Culture Principals leadership of change and stability in Three case studies, Newjersy: Prentice Hall, Englewood.

68- Macpartland. J. and Epston, D. (1975): "Social class difference in effects of open school student Achievement". Diss. Abst. Inter. Vol. 4, PP. 435.

69- Marklag and Ridman (1986): "The Effect of difference sexual on behaviour creativity and Loucs of control for children in fate childhood". Journal of Psychology, Vol. 5, PP. 630-637.

70- Marlow Ediger (2000): "Speaking Activities and reading" Journal Articles, Vol, 37, PP. 137-146.

71- Marsh, H., W., Parker, J. 8 Barnes (1985): "Mulk- dimensional adolescent self-concepts : their relationship to age, sex and Academic measures ${ }^{{ }^{\prime}}$ American educational Research Journal 22(3), PP. (422 -444).

72- Mary, M. Christopher (2003): "Outside - the box thinking yields creative solutions: manager shares in sights on working in education". Journal education, management July, Vol. 7, PP. 80 (3).

73- Mary-M. Christopher and others (2004: "Raising the bar encouraging high level thinking in online discussion forums", report Review, Spring, Vol. 26, PP. 166 (6).

74- Mboya, Mzobanzi, M (1989):"The Relational importance of global self-concept and self-concept of academic ability in predicating academic achievement". Adolescence Vof. 240, No. 83, PP. 39- 46.

75- Michaela Driver (2001): "Fostering creativity in business, education developing creative classroom environments to provide

Doi: $10.12816 / 0034808$ 
students with critical workplace competencies, journal of education for business.

76- Pannuci, M.R (1978): "the relationship of sex and ethnicity to anxiety self-concept and creativity among continuation high school students". Diss. Abst. Inter. Vof 38, No. 7, PP. 40564057 (A).

77- Patricia Csank, Michael Conway (2004): " Engaging in selfreflection changes self-consept clarity : on differences between women and men, and lout and high-clarilg individuals " A journal of research Applied. Vol. 50, No.(7-8) PP.469.

78- Peter Kahn, Fiiednan Batya (1998): " on Nature and Environmental educational Black Parents Speak from the Innercity" Environmental education research", Vof 4, Feb, No. 1, PP. 25 -39 .

79- Petkus, Ed. Jr. (2002): "the creative Identity Creative Behavior from the symbolic interactionsist perspective". Journal of Creative Behavior, Third Quarter Vof 30, No. 3, PP. 88 -96..

80- Plallana. D.J. (1959): "A theory of Personality Types Environment Models" American Psyology Association, Vol. 6, P. 33-39.

81- Raehelle, R,B(1977): "Measurement of perceived Barriers to occupational aspirations of institutionalized adolescents in relation to self-concept and intelligence Diss. Abst. Inter, Vof 38, No. 7, PP. 4033.

82- Ramey, C.T. and P.Per, (1974):" Creativity in Open and Traditional classrooms" 'Child Development, P. 45.

83- Ray, G.A (1974): "A Study of the relationship between teacher educational attitude and action of student creative Behavior and student creative potential and preference for creative behavior", Diss Abst. Inter, Vof 35, No. 5.

84- Redely, W.B and Langmeyer and Ashe (1978): "Selfconcept School Self-image Satisfaction in evolvement in an alternative highschool Psychology in the Schools". Vof 15 (1), Eric. 2109. No. 61, PP. (66-71).

85- Reinecke, M. Louis (1975): "The effectiveness of a creative Free play Program for kindergarten children " Diss. Abs. Inter. Vol. 35, No. 11, 7046 (A).

86- Robinson, Alan (1987): "A. Program to incorporate high order thinking Skills into teachers and learning for grads" Report Research practicum, Nava University. 
87- Rogers, C.R. (1960): "The organization of personality Arpee. Psychologist. Oxford university press, P. 264,

88- Sarah Murray (2003): "A Space for more creative thinking archifcture and design. North American Schads re constructing a new wave of Building that encourage open, Flexible interactive learning", The financial times, April 14, PP. 14.

89- Shobhana, W (1981): "Creative education", Psychological Abstract, Vol. 65, No. 4.

90- Smolensky Kleiner (2015): How to student to think more creativity, Development Review, Vol8, No.6, PP(28-33).

91- Sternberg, R.J\& Ohara, L. (2014): creativity And Intelligence, New york, Cambridge university Press.

92- Tarek C-Granthan Donna (2003): "Bey and Selfconcept and selfesteem: reacial identity and gifted African American students", high school Journal Oct-No.1, vol. 87, P. 18(12).

93- Thaima et al. (1988): "Human Sex Differences in Self concept Psychosocial development Telavivo Ramat. Aviv, is real Journal of Genetic Psychology., Sep, Vol. 149, (3), PP. 405411.

94- Timothy Cathin (2004): "Le Corbusier and the concept of Self Corbusian Sociaties " The Architectureal Review Feb, v. 15, P 96(1).

95- Torrance, E.P. (1969): "Predication of adult creative Achievement among high School Serious". The gifted child Quarterly, Vol. XIII, No. 4.

96- Ursula Athenslaedt, Elisabeth Stephanie Schwab (2004): "Gender robe Self-concept and gender -typed communication behavior in mixed-sex and same - sex dyads. J. of Research, Vol. 50 P. 37 (16).

97- Wakefield, John (1991): "Is creative thinking Normally Distributed " paper presented at the Annual Meeting of the Southeastern Psychological Association (New Orleans), L, A March. PP. 20-23

98- Wallach, M.A, and kogan, N. (1965): "Modes of thinking in young children. A study of creativity intelligence distinction" NewYork Rinfort and wiston.

99- Wilsh, W.B., (1975): "Some theories of Person Environment interaction". Journal of collage student personnel, Vol. 16, P.80 - 105 .

Doi: $10.12816 / 0034808$ 